\title{
Türkiye'deki Suriyeli Göçmenlerin Girişimcilik Faaliyetlerinde Farklı Sermaye Biçimlerinin Rolü ${ }^{1}$
}

\author{
Suvat Parin² ve Ali Rıza Kılıç3
}

$\ddot{O} z$

Göc sürecinin bir sonucu olarak ortaya çıkan gö̆men girişimciliği olgusu; göçmenlerin çeşitli iliş̧kiler ve bağlamlar içinde göş ile gidilen ülkede kendi hesabına çalışması olarak tanmlanabilir. 2011 ynlnnda Suriye'de başlayan is savass sonrasinda Türkiye'ye gọ̈ ile gelen dört milyona yakin Suriyeli, Türkiye'nin çessitli kentlerinde hayatlarm sürdürmektedir. Suriyeli göcmenler vatanlarna dönmeyi beklese de is savas on ynh askem bir süredir devam etmektedir. Bu durum Suriyeli gögmenlerin Türkiye'de kahcı olma isteklerini arttrmaktader. Bu eğilimin etkisiyle, Türkiye'deki gösmen girișimcilik faaliyetlerinde de ciddi bir artss gö̈lenmektedir. Bu çalssmada Suriyeli göcmen girişimcilerin isletme kurma süreçlerinde farkel sermaye biçimlerinin nasil bir rol oynadiğ ortaya konulmaya

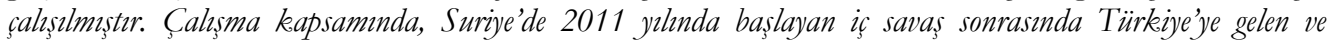
Esenyurt ilçesinde bir işletmeye sabip olan Suriyeli göcmenlere ulaşılmaya çalısıllmıştır. Calışmada nitel araştırma yöntem ve teknikleri kullamlarak. Suriyeli gögsmen girişimcilerin deneyimleri anlasılmaya ve yorumlanmaya

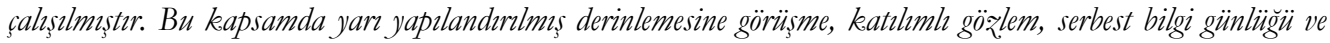
enformel sobbetler aracilgğgyla çalşsma yürütülmüstür. Calssma sonucunda ekonomik, sosyal ve kültürel sermaye biçimlerini ellerinde bulundurmalaryla paralel olarak gọ̈menlerin girişimcilik faaliyetlerine başlayabildikleri ve devam ettirebildikleri görülmüstür.

Anahtar Kelimeler: Uluslararası göc; Göcmen girişimciliği

\section{ABSTRACT IN ENGLISH}

The Role of Different Forms of Capital in Entrepreneurial Activities of Syrian Migrants in Turkey

The phenomenon of immigrant entrepreneurship as a result of the migration process can be defined as the selfemployment of migrants within various relationships and contexts in the host country. Approximately four million Syrians who came to Turkey after the civil war that began in Syria in 2011 have been living in various cities in Turkey. While Syrian immigrants were waiting to return to their homeland, the civil war has been going on for more than ten years. This situation makes the desire of Syrian immigrants to stay in Turkey permanently, increased. In parallel with this trend, a significant increase is observed in migrant entrepreneurship activities in Turkey. In this context, this study aimed to explain how different forms of capital play a role in the processes of Syrian immigrant entrepreneurs' transformation into business owners. The study aims to reach Syrian migrants who arrived in Turkey after the civil war in Syria that began in 2011 and who owned a business in the Esenyurt district. In this study, by using qualitative research methods and techniques, the experiences of Syrian migrant entrepreneurs are tried to be

\footnotetext{
${ }^{1}$ Bu çalışma Van Yüzüncü Y1l Üniversitesi Sosyal Bilimler Enstitüsü Sosyoloji Yüksek Lisans programında yazılan “Türkiye'deki Suriyeli Göçmenlerin Girişimcilik Faaliyetleri Üzerine Bir Araştırma-İstanbul/Esenyurt Örneği’” adlı tezden üretilmiştir. İlgili tez 7357 adlı proje olarak Van Yüzüncü Yıl Üniversitesi BAP Birimi tarafindan desteklenmiştir.

${ }^{2}$ Prof. Dr. Suvat Parin, Van Yüzüncü Y1l Üniversitesi Sosyoloji Bölümü, Van, Türkiye. E-mail: sparin@yyu.edu.tr. ORCID: 0000-0001-9833-7549

3 Araş.Gör. Ali Rıza Kılıç, Van Yüzüncü Yıl Üniversitesi Sosyoloji Bölümü, Van, Türkiye. E-mail: alirizakilic@yyu.edu.tr. ORCID: 0000-0002-4241-5007
} 
16 Türkiye'deki Suriyeli Gösmenlerin Girişimcilik. Faaliyetlerinde Farkh Sermaye Biçimlerinin Rolü

understood and interpreted. As a result of the study, it has been seen that different forms of capital play a role in different levels of the entrepreneurial activities of immigrants.

Keywords: International migration; Immigrant entrepreneurship

\section{Giriş}

2010 yılının aralık ayında Tunus’ta başlayan, sonrasında Kuzey Afrika ve Ortadoğu'daki birçok ülkede toplumsal ve siyasal dönüşümlere neden olan ve “Arap Baharı" olarak adlandırılan protesto ve ayaklanmalar zinciri Suriye'de bir iç savaşa dönüşmüştür. Suriye'de barışç1l gösteriler yerini silahlı çatışmalara bırakmış, şiddet eylemlerinin artmasıyla birlikte Suriye vatandaşları ülkenin daha güvenli yerlerine ve Suriye'nin sınır ötesine göç etmiştir. Suriye'de yerinden edilmiş insan sayısı 6 milyonu aşmış, Suriye'nin komşu ülkelerinde yaşayan insan sayısı ise 5 buçuk milyonun üzerine gelmiştir (BMMYK, 2021). Türkiye, Suriye İç Savaş1 sırasında açık kapı politikası uygulamış ve sınırlarına dayanan göçmenleri kabul etmiştir. Türkiye sınırları içinde resmi kayıtlara göre 2021 yılı Eylül ayı itibariyle 4 milyona yakın Suriyeli göçmene ev sahipliği yapmaktadır (BMMYK, 2021).

Türkiye’deki Suriyelilerin küçük bir bölümü (\%1,5’i) (GİGM, 2021) Suriyeli göçünün başında oluşturulan Geçici Barınma Merkezleri (GBM)'nde yaşamakta çoğunluğu ise Türkiye'nin bütün kentlerine yayılmış bir şekilde hayatlarını sürdürmektedir. GBM’lerde Suriyelilerin temel yaşamsal gereksinimleri karşılanmakta bunların dışında kalanlar ise kısmi olarak çeşitli kurumlardan yardım almakla birlikte hayatlarını kendi olanaklarıyla sürdürmektedir. Suriyeliler çoğunlukla ağır çalışma koşulları, düşük ücret, ayrımcıllı gibi sorunlarla karşı karşıya kalmaktadır (TEPAV, 2021). Suriye göçünün ilk yıllarında savaşın yakın zamanda biteceği umuduyla daha çok Türkiye'nin Suriye sınırındaki kentlerde yaşayan Suriyeliler, geri dönme umutları tükendikçe Türkiye'nin büyük şehirlerine göç etmeye başlamıştır. Bunun yanında geri dönme umudunu yitiren göçmenlerin bir bölümünün Türkiye'de kalıcılaşma ve var olan birikimlerini burada değerlendirme eğilimleri artmaktadır. Burada birikimden kasıt sadece ekonomik bir değer toplamı değildir. Burada birikim ile kasıt göç edenin göç öncesinde sahip olduğu ve göç ile gelinen ülkeye taşıyabildiği toplumsal, kültürel, iktisadi değerler ve sosyal ilişkilerle birlikte göç ile gelinen ülkede üretilen ve yerlileri de içine alan bir ağ ve değer bütünüdür. Bu birikimin değerlendirilme biçimlerinden biri olan göçmenlerin geldikleri ülkede kendi hesaplarına çalışarak işletme kurma yani girişimci olma eğilimleri Türkiye'deki Suriyeliler arasında da güçlenmektedir.

Türkiye'deki Suriyeliler tarafından göçün başladığı 2011 yılından bu yana çeşitli illerde sayısı binlerle ifade edilen işletme kurulmuştur. TEPAV'ın 2019 yılında yayınladiğı "Syrian Entrepreneurship and Refugee Start-ups in Turkey: Leveraging the Turkish Experience" adlı raporda, sekiz y1l boyunca Türkiye'deki Suriyelilerin, yüzde 60'1 Suriyeli olan ortalama 7 kişinin çalıştı̆̆1 10.000'den fazla şirket kurduğu belirtilmiştir (TEPAV, 2019). Türkiye'de Suriyeliler tarafından kurulan işletmelerin illere göre dağılımına bakıldığında Suriyeli nüfusun en fazla olduğu il olan İstanbul, Suriyelilerin işletme kurdukları illerin de başında gelmektedir. İstanbul'da Suriyeliler tarafindan 2017 y1linda 593, 2018 y1linda 976, 2019 y1linda 563, 2020 y1linda ise 287 işletme kurulmuştur (TOBB, 2021). İstanbul Ticaret Odası (ITO) ve İstanbul Esnaf ve Sanatkârlar Odaları Birliği (İSTESOB) verilerine göre Ağustos 2018 tarihine kadar İstanbul'da Suriyelilerin kurduğu işletme sayıs1 5617'si İTO'ya, 469'u İSTESOB'a kayıtlı olmak üzere toplam 6086'dır (İTO, 2018; İSTESOB, 2018). Herhangi bir kayd1 olmadan ticari faaliyetine devam eden Suriyeli işletmelerin de varlığı, gerçek sayının bunun üzerinde olduğunu

Göç Dergisi 
göstermektedir. Esenyurt, İstanbul'da Suriyelilerin en fazla işletme kurdukları ikinci ilçe olmasıyla ön plana çakmaktadır. Özellikle 2015 ylından sonra bu ilçedeki Suriyeli işletmelerin sayısında ciddi bir artış gözlenmiştir. Suriyeli göçmenlerin Esenyurt’ta kurduğu işletme sayısı 708'i İTO'ya ve 52'si İSTESOB'a kayıtlı olmak üzere 760'dır (ITTO, 2018; İSTESOB, 2018). Saha çalışmasındaki gözlemlerde de tanık olunan önemli sayılaki kayıt dışı faaliyet gösteren işletme de dahil edildiğinde sayının bundan daha fazla olduğu düşünülmektedir.

Bu çalışma 2018 yllında İstanbul ili Esenyurt ilçesinde Suriyeli işletme sahipleri arasında yapılan saha araştırmasına dayanmaktadır. Göçmenlerin girişimcilik deneyimlerinin yoğun olduğu bir alan olması Esenyurt bölgesini incelemeye değer kılmışır. Bunun dışında Türkiye'de Suriyeli göçmen girişimcilerle ilgili çok az çalışmanın olması, Esenyurt özelinde ise bu konu ile ilgili herhangi bir çalışmaya rastlanılmaması araştırma alanı olarak bu bölgenin seçilmesini etkilemiştir. Çalışma Suriye iç savaşı sonrası Türkiye'nin en büyük metropolü olan İstanbul'un ekonomik ve nüfus açısından hızla büyüyen Esenyurt ilçesinde işletmeler kuran Suriyeli göçmenlerin bu faaliyetlerini Pierre Bourdieu'nun kavramsal araçlarından olan sermaye biçimleri (Bourdieu, 2010) ile analiz etmeyi amaçlamıştır. Göçmenlerin belli oranlarda sahip olduğu ekonomik, kültürel ve sosyal sermayelerinin girişimcilik süreçlerinde nasıl bir rolü olduğu çalışmanın önemli sorunsalıdır.

Göçmenlerin girişimcilik faaliyetleri ile ilgili akademik ilgi ve bu alanda yapılan çalşmalar son yıllarda artış göstermiştir. Genellikle işletme, ekonomi, iktisat gibi disiplinlerin üzerine eğildiği göçmen girişimciliği konusunda sosyoloji alanında da çalışmalar artmaktadır. Türkiye'de de göçmen girişimciliği ile ilgili çalışmaların genellikle iktisadi bölümlerde yapılmış olması bu konuya sosyolojik bir perspektif sunma iddiasında olan bu çalışmayı önemli kılmaktadır.

Göçmen girişimciliği ile ilgili var olan yaklaşımların eksikliklerinin aşılmasını sağlamak için alan yazında çeşitli eleştiriler geliştirilmektedir. Bu eksikliklerin aşılması için göçmen girişimciliği konusunda Bourdieu'nun bütünlüklü ve ilişkisel yaklaşımı ilgi çekmektedir (Karan, 2019). Özellikle Bourdieu'nun sermaye kavramı göçmen girişimciliği faaliyetlerinin anlaşılmasında önemli olanaklar sunmaktadır (David, Schäfer, \& Terstriep, 2021; Atasü-Topcuoğlu, 2019). Bu çalışma göçmen girişimciliği konusunu sermaye biçimleri kavramı sşığında ele almaktadır.

\section{Göçmen Girişimciliği}

1970’li yıllardan bu yana etkisi ve kuşatıcllı̆g giderek artan küreselleşme olgusuyla paralel olarak, uluslararası göçlerin daha önce olmadığı kadar hacmi artmış ve dünya üzerindeki ülkelerin neredeyse tamamını etkisi altına alacak bir düzeye gelmiştir. Böylece milyonlarca farklı renk, kültür, etnik kimlik, dil, din ve mezhep aidiyetli insan anavatanından başka bir ülkeye göç etmiş ve bu ülkede yerleşmeye başlamıştır. Göçmenlerin büyük kısmı özellikle gelişmiş ekonomilere sahip ülkelerde ucuz işgücü olarak iş piyasasına katılmaktadır. Ev sahibi topluluk mensubu işçilerle aynı işleri yapmalarına karşlık daha düşük ücret alan göçmenler bunun yanında birçok alanda ayrımcllğa uğramaktadır. Sosyo-ekonomik zayıflıklarının yanında dil, meslek ve eğitim konusundaki eksiklikleri gibi nedenler göçmenleri göç ettikleri ülkede kendi hesabına çalışmaya yönlendirmektedir. Göçmenlerin aynı kökenden veya menşei ülkeden insanlarla varolan ve yeni kurdukları sosyal ilişkilerin göç edilen ülkede girişimcilik faaliyetlerini kolaylaştırıcı etkileri de bulunmaktadır. Bunun yanında göçmenler sadece karşılarına çıkan engellerden ve zorunluluklardan dolayı girişimciliğe yönelmemektedir. Göçmen girişimcilerin bazıları aynı zamanda iyi bir iş firsatından yararlanmak için özgürce kendi işletmelerinin sahibi olmak isteyen kişiler de olabilir (Chrysostome, 2010: 138). 
Göçün sosyo-ekonomik açıdan en belirgin etkisi serbest meslek sahibi göçmenlerin artan oranı olup birçok göçmen grubun girişimci davranış1 "göçmen girişimciliğì" veya "etnik girişimcilik" olarak adlandırılan yeni bir olgunun yükselişine neden olmuştur (Baycan-Levent \& Nijkamp, 2009: 377). Göç edilen ülkede göçmenlerin kendi hesabına çalışma eğilimlerinin güçlenmesiyle akademik yazında bu kavramlar tartışılmaya başlanmıştır. Bazı çalışmalarda, göçmen girişimci ile etnik girişimci arasındaki ayrım her zaman belirgin değildir. Bazı yazarlar "göçmen girişimci" ve "etnik girişimci" terimlerini birbirlerinin yerine kullanmaktadır, ancak çoğu yazar iki ayrı özel grubu tanımlamak için bu terimleri kullanma eğilimindedir. Örneğin, Light (1972) ilk kuşak göçmen girişimci ile ikinci kuşak etnik girişimci arasında ayrım yapmak için "göçmen girişimci" kavramını kullanmayı önermektedir. Chaganti ve Greene (2002), "etnik girişimciyi" nesiller ne olursa olsun, bir bireyin etnik bir yerleşim bölgesi ile özdeşleşmesinin gücünün bir işlevi olarak tanımlar (Fregetto, 2004: 255). Diğer yandan etnik ve göçmen girişimci tanımlamaları yanında yabancı girişimciler azınlık girişimci olarak da tanımlanabilmektedir (Chaganti ve Greene, 2002: 128). Yaptıkları çalışmada Chaganti ve Greene (2002) ; Butler ve Greene (1997), Waldinger ve diğerleri (1990) ile Amerika Birleşik Devletleri (ABD) Ticaret Departmanı'nın (1997) tanımlamalarını bir araya getirilmiştir. Buna göre; Butler ve Green (1997) göçmen girişimcileri, hedef ülkeye varılmasından hemen sonrasında, o ülkede bulunan göçmenlerle ve aynı kökenden göçmen olmayanlarla bireysel ilişkileri vasıtasıyla işletmeler açan kişiler olarak ifade eder. Waldinger ve diğerlerine göre (1990) etnik girişimciler "ortak ulusal arka planı veya göç deneyimlerini paylaşan insanlar arasında bir dizi bağlantı ve düzenli etkileşim kalıpları" yaratırlar. A.B.D. Ticaret Departmanı ise, yabancıların iş sahipliğini ülkedeki baskın topluluğun dışındaki “azınlık girişimciler” gibi tanımlar (Chaganti ve Greene, 2002: 128). Daha önce yapılan çalışmalarda kendi hesabına çalışan göçmenler için 'göçmen girişimciler", “azınlık girişimciler”, “etnik girişimciler” gibi farklı tanımlamalar yapıldığ1 görülmektedir. Azınlık, bir toplumda baskın grup olmayan herhangi bir gruba atıfta bulunurken; göçmen, yakın zamanda başka bir ülkeden gelenlere atıfta bulunur. Aradaki fark, yüzyıllar öncesinde göç etmiş olan ve hala bir azınlık grubu olan Afro-Amerikalılara karşın göçmen ve azınlık olan New York City'deki Jamaikalılar örneğinde görülebilir (Roberts, 2009: 85). Ayrıca aynı ülkeden bir başka ülkeye göç eden insanların hepsinin aynı etnik kökene sahip olmama ihtimali de mevcuttur. Diğer bir deyişle göçmen girişimciliğinin etnik girişimciliğini de içine alan bir kavram olduğu görülmektedir. Bu anlamda birbirleri yerine çoğunlukla kullanılsa da bu kavramlar farklı durumları karşılamaktadır. Bu kavramsal açıklamalar 1şığında geniş bir tanımı yapılacak olursa göçmen girişimciliği, "belirli bir sosyo-kültürel ve etnik kökene veya menşei ülkeye ait göçmenler tarafından yapılan iş faaliyetleridir”" (Sahin vd., 2009: 253).

Birçok çalışma, serbest meslek sahibi olma eğilimini veya kabiliyeti anlamında yerli halkla göçmenler arasında farklılıklar olduğunu göstermiştir. Genel olarak, göçmenlerin serbest meslek sahibi olma oranları birçok ülkede yerli olanları aşarken, göçmenlerin benzer vasıflara sahip yerli çalışanlara göre serbest meslek sahibi olma olasılıkları daha yüksektir (BaycanLevent \& Nijkamp, 2009: 378). Göçmen işletmelerin giderek birçok göç alan ülkede artmas1 ve bu durumun çeşitli alanlarda etkilerinin ortaya çıkması, konu ile ilgili akademik ilgide de bir artış doğurmuştur. Böylece göçmenlerin girişimcilik faaliyetleri hakkında pek çok çalışma yapılmıştır. Basu \& Altunay, 2002; Baycan-Levent vd., 2003; CEEDR, 2000; Choenni, 1997; Delft vd., 2000; Fatoki \& Patswawairi, 2012; Greenwood, 1994; Masurel vd., 2002; Matricano \& Sorrentino, 2014; Min, 1987; Nijkamp, 2003; Nişanc1, 2015; Ramadani vd., 2014; Sanders \& Nee, 1996; Taş \& Çiftçi, 2009; Waldinger, 1984; Waldinger vd., 1990; Ward \& Jenkins 1984; 
Wahlbeck, 2007; Vinogradov ve Gabelko, 2010 bunlardan bazılarıdır (Baycan-Levent \& Kundak, 2006: 405; Güngördü, 2018: 60-62).

Genel olarak literatürde göçmen girişimciliği ile ilgili yapılan çalışmalarda göçmen girişimciler açısından başarının ve performansın koşullarıyla göçmen girişimciliğine yönelik firsat ve engel durumları tanımlanmıştır. Yapısal etkenler (toplumsal dışlanmaya maruz kalma, ayrımcı yaklaşımlar, piyasaya erişimdeki zayıflık ve yüksek seviyedeki işsizlik), kültürel etkenler (spesifik değerlere, becerilere sahip olma, grup içi sadakatin varlığı, kişisel güdüler, çalışkanlık, etnik topluluklanyla informel ağ ilişkileri) veya bunların birlikteliği (Waldinger vd. tarafindan (1990) tanımlanan etkileşim modeli) bahse konu çalışmalar içinde araştırılmıştır (BaycanLevent \& Kundak, 2006: 406).

Göçmenleri girişimcilik faaliyetlerine katılmasını etkileyen birçok faktör mevcuttur. Bu faktörler kabaca teşvik edici ve sevk edici faktörler olarak ikiye ayrrlabilir. Göçmenleri girişimciliğe yönlendiren sosyal dışlanma, göç edilen ülkenin dilini bilmeme, beceri ve eğitim eksikliği, göç edilen ülkedeki yüksek işsizlik oranları, göçmen işçilere dayatılan düşük ücret, yüksek vasıf ve göç ile gelinen ülkeden alınması gereken diploma gibi ön şartların olduğu ve bundan kaynaklı ezici bir çoğunluğu ev sahibi topluma mensup çalışanlardan oluşan birincil iş piyasasına katılamama gibi sevk edici faktörler bulunmaktadır (Strüder, 2003: 8). Göçmenlerin kendi hesabına çalışmasını teşvik eden faktörler de mevcuttur. İş firsatlarından yararlanmak, kendi işletmesini tek başına kurma ve yürütme isteği, ev sahibi toplumda ve göçmen toplumunda prestij sahibi olma isteği, daha yüksek bir gelire sahip olma isteği, yetenek ve becerileri yardımıyla amaçlanına ulaşmak gibi teşvik edici faktörler göçmenlerin kendi işini kurmasinda motive etmektedir.

Bütün bu itici ve çekici faktörler yanında ülkelere, her bir göç hareketine göre ciddi farkl1lıklar gösteren ve göçmen girişimciliğini etkileyen yapısal nedenler de bulunmaktadır. Yerel koşullar, göç nedeni, göç edilen ülkenin göç yasası ve politikaları, göçmen topluluğun varlı̆̆1 ve ekonomik bütünlüğü, girişimciliği teşvik eden veya zorlaştıran kurumsal faktörler ve göç edilen ülkenin sosyo-kültürel bağlamı (örneğin, göç tarihi, yabancıların işgücü piyasasına erişimine ilişkin devlet mevzuatı) göçmen girişimciliği süreçleri üzerinde etkili olmaktadır (BaycanLevent \& Nijkamp, 2009: 394).

Gelişmiş ekonomilerde göçmenler genellikle işgücü eksikliğini kapatmak için ülkeye getirilen veya izin verilen düşük vasıflı işçiler olarak kabul edilmekteydi. Ancak özellikle 1970’li yıllardan sonra küçük ve orta işletmeye sahip olan göçmen girişimciler dikkatleri kendi üstlerine çekmeye başlamıştır. Kendi hesabına çalışan göçmenler, uluslararası göçün hacminin muazzam seviyelere ulaşmalarının bir sonucu olarak çeşitli ülkelerde işletmeler açmaktadır. Göçmenlerin kendi hesabına çalışma oranlanındaki artış; göçmenler ve ailelerine, ev sahibi topluma, göçmenlerin göç ile yerleştikleri ülkelere ve geride bıraktıkları anavatanlarına ekonomik sosyal ve kültürel faydalar sağlamaktadır. Göçmen girişimcilerin kendi işletmelerini kurmaları, kendilerine iş yaratmış olmalarının yanında yeterliliklerin tanınmaması veya düşük seviyede olması, zayıf dil bilgisine sahip olma ve ilgili sosyal ağlara yetersiz erişim veya yerel işverenler tarafından yapılan ayrımcılık gibi iş ararken karşılaşabilecekleri bazı engelleri aşmalarını sağlar. Bunun yanında göçmen işletmeler diğer göçmenler ve yerel çalışanlar için istihdam sağlayabilmektedir. Çoğu zaman göçmen işletmeler yerli girişimcilerin sunma ihtimalinin yüksek olmadığı mal ve hizmetler sunmaktadır (Kohlmeier ve Schimany, 2005: 25). 


\section{Türkiye'deki Suriyeli Göcmenlerin Girişimcilik. Faaliyetlerinde Farkh Sermaye Biçimlerinin Rolü}

Ekonomik faydalarının yanında göçmenlerin iş piyasasına girmesi göçmenlerin sosyal entegrasyonunun ilk adımı olarak görülmektedir. Bunun dişında göçmenlerin kurdukları işletmeler yeni gelen göçmenlerin daha önce göç etmiş göçmenlerle ilişki kurabileceği, göçmen ağlarıyla tanışabileceği bir irtibat noktası olarak da düşünülebilir. Göçmenlerin kendi içindeki dayanışmasının bir mekânı olabilen göçmen işletmeleri aynı zamanda o topluluğun kendini ev sahibi topluma ve diğer göçmen topluluklanına sunma işlevi de görmektedir. Göçmenlerin beraberinde getirdiği dil, kültür, inanç, moda, yeme-içme alışkanlığı gibi birçok formun göçmen girişimciler tarafindan ev sahibi toplum ve diğer göçmen topluluklara sunulması bu gruplar arasında bir alışveriş ve aktarım yaratmaktadır. Örneğin, Berlin'deki bir Alman sadece kendi toplumunun ve ülkesinin gelenek, kural ve kültürüne değil, aynı zamanda dünyanın birçok ülkesinden gelen göçmenlerin kendi ülkelerine dair yerel gelenek, kural, kültür, inanış, moda, yeme-içme alışkanlıklarıyla birebir temas etme ihtimaline sahiptir. Küreselleşmenin sonuçlanı içinde sayabileceğimiz bu imkân ve ihtimaller göç ile küreselleşme arasındaki ilişkiyi düşündüğümüzde göçün de doğrudan sonuçları olmaktadır.

\section{Sermaye Biçimleri}

Pierre Bourdieu'nun temel kanısına göre, sosyal dünya, farklılık ve dağılım ilkelerine göre yapılandırılmış çok boyutlu bir ortamdır. Objektif güç ilişkilerinin bir araya geldiği bu ortamda, aktörler sosyal olarak konumlandırılır ve bu konumlandırma rastgele olmamaktadır. Bu konumlandırma aktörlerin değişik formlara bürünebilen sermaye çeşitlerine sahip olma ve bunları kullanabilme yeteneğine dayanmaktadır (Neumann, 2011: 300).

Bourdieu'ya göre sermaye birikmiş emektir. Sermaye, ya maddileşmiş halde ya da yoğunlaşmış ve içleştirilmiş halde biriktirilen iştir (Bourdieu, 2010: 45). "Sermaye, aktörlerin veya grupların düşünce ve davranışlanını formüle ettikleri, topluma ait alışkanlık, kodlama veya kalıpların bütünüdür. Söz konusu bu formülasyon neticesinde aktörler ya da gruplar davranışlarının meşruluğunu sağlarlar. Zamanla ve yeni davranışlar yoluyla sermaye kendini yeniden üretir" (Yarc1, 2011: 130). Bireyler ya da sınıflar arasında sermayenin dağıllımı onların başanı şanslarını belirler (Bourdieu, 2010: 46). Bu anlamda "sermaye, kişinin belirli bir toplumsal alana katılımını ve bu alan içinde rekabetin getirdiği özel kazançlara ulaşmasını mümkün kılan etkili bir kaynaktır" (Wacquant, 2016: 62).

Sermaye metaforuyla Bourdieu, sırf finansal refahı kastetmez, daha ziyade 'sosyal enerjinin' şeyleştirilmesiyle ya da kristalleştirilmesiyle üç farklı formu birbirinden ayırır: ekonomik sermaye, hemen ve doğrudan paraya dönüştürülebilir ve mülk edinme hakkı biçiminde kurumsallaştırılır, temel değişim değeri paradır ve ekonomik statü biçiminde görünür; kültürel sermaye, belli koşullar altında iktisadi sermaye biçimine dönüştürülebilir ve eğitim nitelikleri biçiminde kurumsallaştırılır, yani o sosyalleşme sürecinde uzun vadeli meyilleri -dispositionsve alışkanlıkları kapsar, resmi eğitim nitelikleri ve öğretimleri gibi değerli kültürel nesnelerin birikimidir; sosyal sermaye, sosyal yükümlülüklerden oluşur, bunlar belirli koşullar altında ekonomik sermayeye dönüştürülür ve soyluluk biçiminde kurumsallaştırılır, sosyal temas ve bağlantılar temel değişim değeridir, üyelik biçiminde görünür hale gelir (Arun, 2010: 29). Sosyal sermaye, "bir bireyin ya da bir grubun, kalıcı bir ilişkiler ağına, az çok kurumlaşmış karşılıklı tanıma ve tanınmalara sahip olması sayesinde elde ettiği gerçek ya da potansiyel kaynakların toplamıdır, yani böylesi bir ağın harekete geçirmeye olanak sağladığı sermaye ve güçlerin toplamıdır" (Bourdieu ve Wacquant, 2003: 108). Nohl (2008), Bourdieu (1986)'den hareketle kültürel sermaye için "Bir insanın okulda ve okul dışında, özellikle ailesinde edindiği bilgi ve

Göç Dergisi 
beceriler, ancak başkaları tarafından tanınınca kültürel bir sermaye haline gelebilir, yani kapitalist üretim alanında değerlendirilebilir" demektedir. Bourdieu’ya göre kültürel sermayenin üç hali mevcuttur. "Bilgi ve becerilerin bir sertifika haline getirildiği yerde (örneğin okul yada üniversite diplomasında), 'kurumsallaşmış kültürel sermaye'den söz edilir. Kültürel sermayenin 'bedenselleşmiş' hali ise adeta habitusun bir parçası olmuş ve uzun vadeli toplumsallaşma ve öğrenme süreçlerine dayanır" (Bourdieu 1986'dan aktaran Nohl, 2008: 4041). Son olarak kültürel sermaye nesneleşmiş halde, kültürel emtia biçiminde (resimler, kitaplar, sözlükler, enstrumanlar, makineler vd.) bulunabilir (Bourdieu, 2010: 49).

Başka bir sermaye biçimi durumundaki sembolik sermaye gerçekte insanların sermaye olarak algılamadığ1, belli bir sermaye şeklinin tesirine işaret eder (Wacquant, 2016: 62). Sembolik sermaye, ekonomik, kültürel ve sosyal sermaye biçimlerinin herhangi birinin sosyal düzende algılanmasıyla aldığı yeni haldir (Bourdieu \& Wacquant, 2003:108). Sembolik sermaye eyleyicilerin sosyal yaşamda yapıp ettikleri ile diğer eyleyiciler tarafindan fark edilmelerine ve tanınmalarına olanak tanımaktadır. Bireyin tanınmasına-yanlış tanınmasına olanak sağlayan alg1yı belirleyen, onur, şöhret gibi değerlere sahipliğin ölçütü sembolik sermayenin miktarı ile belirlenmektedir.

\section{Araştırmanın Yöntemi}

Araştırma yöntemi, araştırmadaki hedeflere varılması için izlenen yol olarak tanımlanabilir. İstanbul ili Esenyurt ilçesindeki Suriyeli göçmenlerin girişimcilik deneyimlerine odaklanan bu çalışmada, nitel araştırma yöntem ve teknikleri kullanılmıştır. Derinlemesine görüşme nitel araştırmalarda sıklıkla kullanılan bir veri toplama tekniğidir. Bu araştırmada, derinlemesine görüşmenin türlerinden biri olan yarı-yapılandırılmış görüşme tekniğinden yararlanılmıştır.

Araştırmanın kapsamında Suriye'de 2011 yılında başlayan iç savaş sonrasında Türkiye'ye gelen ve Esenyurt ilçesinde faaliyet yürüten Suriyeli göçmen girişimcilere ulaşılmaya çalış1lmıştır. Saha araştırması olarak belirlenen bölgeye gidilmeden önce Ekim 2017 ile Haziran 2018 tarihleri arasında, konu ile ilgili daha önce yazılmış makale, tez, rapor gibi çalışmalar incelenerek bir literatür taraması yapılmıştır. Mart 2018'de saha araştırmasının yapılacağ1 Esenyurt ilçesi Bağlarçeşme ve Balıkyolu mahallelerinde bir hafta süreyle gözlemler yapılmış ve Suriyeli göçmenlerin işletmelerinin yoğunlaştı̆̆ sokak ve caddeler tespit edilmiştir. Bu sürecin içinde araştırma problemleri 1şığında sahada katılımcılara yöneltilecek görüşme formu hazırlanmıştır. 2018 yılının Temmuz ayında saha araştırması için Esenyurt ilçesine komşu olan Avcılar ilçesinde ikamet etmeye başlanmış ve bu tarihten itibaren saha araştırması başlamıştır. Çalışma 2018 yılının Eylül ayının sonunda sonlandırılmıştır. Çalışmanın yapıldığı Esenyurt ilçesindeki Suriyeli göçmenlerin büyük kısmının Türkçe bilmemesinden dolayı bir tercümanla sahaya çıkılmıştır. Görüşmeler, tercüman aracıllı̆ıyla Arapça dilinde yapılmış ve görüşme esnasında spontane olarak Türkçe diline çevrilmiştir. Sahaya çıkılmadan önce görüşme formu ve çalışmanın temel amacı ve muhtevasıyla ilgili tercümana araştırmacı tarafından bilgiler verilmiş ve yapılacak derinlemesine görüşmelerde nelere dikkat edileceğine karar verilmiştir.

Çalışmanın örneklem seçiminde ilk olarak araştırma amacına yönelik olarak belirli kriterler doğrultusunda oluşturulan amaçsal örnekleme yöntemlerinden kartopu örnekleme yaklaşımını (Yıldırım ve Şimşek, 2018: 122) kullanmak düşünülse de sahada bu yolun işlemediği görülmüştür. İki katılımcı dışındaki Suriyeli işletmeciler çalışma için bir başka Suriyeli işletmeciyi önermeyi ve yönlendirmeyi istememiştir. Bundan kaynaklı olarak saha araştırması sürecinde ulaşılan referans kişiler Suriyeli işletmecilere ulaşmada kilit rol oynamıştır. Birlikte 
çalışılacak Suriyeli göçmenlerin hassas bir grup olması ve ev sahibi toplumdan özellikle tanımadıkları kişilerle görüşmek istememelerinden kaynaklı referans kişilere başvurulmuş ve referans kişiler aracılığıyla katılımcılara ulaşılmaya çalışılmıştır. Referans kişiler dışında tercümanın Suriyeli olması da katılımcılarda güven duygusunu arttırmıştır.

Çalışma kapsamında Esenyurt İlçesinde faaliyet yürüten 20 Suriyeli göçmen girişimciyle derinlemesine görüşmeler yapılmıştır. Görüşmeler 40 dakika ile iki buçuk saat arasında sürmüştür. Yapılan derinlemesine görüşmelerden sağlanan veriler tekrar etmeye başladığında görüşmeler sonlandırılmıştır. Hassas bir gruba mensup olmaları ve güven duygusunun pekişmesi için katılımcılara gerçek isimlerinin saklı tutulacağına dair söz verilmiştir. Söz verildiği gibi gerçek isimleri kullanılmamış; her bir katılımcıya kod isim verilmiştir. Bunun yanında görüşmeler öncesinde katılımcılara araştırmanın kapsamı ile ilgili bilgiler verilmiş, sözlü onayları alınmış ve edinilen bilgilerin gizli tutulacağı belirtilmiştir. Bu görüşmeler yanında çalışmaya konu olan sahada üç aylık bir süre boyunca pasif ve katılımlı gözlemlerde bulunularak ve serbest bilgi günlükleri tutularak göçmen girişimcilerin deneyimleri doğal ortamında anlaşılmaya ve yorumlanmaya çalışılmıştır. Samimiyet kurulabilen işletme sahipleriyle iş yerlerinde, kafelerde ve evlerinde zaman geçirilmiştir. Bu işletme sahipleri sayesinde haftada dört gün Suriyeli göçmenlerin sahip olduğu işletmelerin yoğun olarak bulunduğu Esenyurt'un Bağlarçeşme, Balıkyolu, Koza, Yenikent, Atatürk, Sultaniye ve Turgut Özal mahallelerinde Suriyeli göçmenlerin deneyimlerini ve ilişkilerini gözlemleme firsatı bulunmuştur. 2018 yılının Kasım ayında çalışmanın yapıldı̆̆ı bölgede bir haftalık bir süreyle daha önce görüşülen işletme sahipleriyle enformel sohbetler ve gözlemler yapılmış ve serbest bilgi günlüğü tutulmuştur.

\section{Bulgular}

\section{Demografik Bulgular}

Araştırma sahası olarak seçilen Esenyurt ilçesindeki Suriyeli göçmenlerin işletmeleri gözlemlendiğinde kadın işletmeciye rastlanılmamıştır. Bundan dolayı görüşme yapılan göçmen girişimciler genellikle orta yaş ve üzeri erkeklerden oluşmaktadır. Katılımcılarla ilgili yaş, eğitim, göç ile ayrıldığı ülkedeki ve göç ile geldiği ülkedeki mesleki durum, Türkiye'de kaldığ1 süre bilgileri Tablo 1'de verilmiştir.

Tablo 1. Katılımcılar İle İlgili Bilgiler

\begin{tabular}{|c|c|c|c|c|c|c|c|}
\hline $\begin{array}{l}\text { Sira } \\
\text { No }\end{array}$ & $\begin{array}{l}\text { Kod } \\
\text { İsim }\end{array}$ & Yaş & Eğitim & $\begin{array}{l}\text { Suriye'de } \\
\text { Yaşadı̆̆1 } \\
\text { Şehir }\end{array}$ & $\begin{array}{l}\text { Türkiye'de } \\
\text { Kaldığı } \\
\text { Süre }\end{array}$ & Suriye'de Mesleği & $\begin{array}{l}\text { Türkiye'de } \\
\text { Mesleği }\end{array}$ \\
\hline 1. & Velid & 53 & İlkokul & Halep & $5 \mathrm{Y}_{11}$ & Taksi Şoförü & Market \\
\hline 2. & Anas & 25 & Ortaokul & Halep & $5 \mathrm{Y}_{11}$ & Berber & Berber \\
\hline 3. & Mahzar & 35 & Lise & Şam & $3 Y_{11}$ & Restoran İşletmecisi & Restoran İşletmecisi \\
\hline 4. & Yusuf & 38 & Ortaokul & Halep & $5 \mathrm{Y}_{11}$ & Kamyon Şoförü & Lokantac1 \\
\hline 5. & Hamit & 36 & $\begin{array}{l}\text { Yüksek } \\
\text { Lisans } \\
\end{array}$ & Hama & $6 \mathrm{Y}_{11}$ & $\begin{array}{l}\text { Akademik Personel } \\
\text { (Okutman) }\end{array}$ & Kargo İşletmecisi \\
\hline 6. & Fuad & 46 & Lisans & Halep & $5 Y_{11}$ & İnşaat Şirketi Sahibi & İnşaat Şirketi Sahibi \\
\hline 7. & Adnan & 53 & İlkokul & Şam & $2,5 Y_{11}$ & Ayakkab1 Dükkan1 Sahibi & Toptanc1 \\
\hline 8. & Samir & 29 & $\begin{array}{l}\text { Lisans } \\
\text { Terk }\end{array}$ & Şam & $4 Y_{11}$ & Öğrenci & Restoran İşletmecisi \\
\hline 9. & Hamza & 34 & Lise & Şam & $3 Y_{11}$ & Peçete Fabrikası Sahibi & Lokantac1 \\
\hline 10. & Abdullah & 21 & Ortaokul & Halep & $5 Y_{11}$ & Kozmetik Dükkanı Sahibi & $\begin{array}{l}\text { Giyim Mağazası } \\
\text { Sahibi }\end{array}$ \\
\hline 11. & Halil & 38 & İlkokul & Rakka & $2 Y_{11}$ & Fayans Atölyesi Sahibi & Market \\
\hline
\end{tabular}




\begin{tabular}{|c|c|c|c|c|c|c|c|}
\hline 12. & Mahir & 24 & $\begin{array}{l}\text { Lisans } \\
\text { Terk }\end{array}$ & Halep & $4 Y_{11}$ & $\begin{array}{l}\text { Kozmetik Mağazası } \\
\text { Çalışanı }\end{array}$ & $\begin{array}{l}\text { Kozmetik Mağazas1 } \\
\text { Sahibi }\end{array}$ \\
\hline 13. & Ahmet & 31 & Lise & Halep & $6 Y_{11}$ & $\begin{array}{l}\text { Çelik Ürünleri Fabrikası } \\
\text { Sahibi }\end{array}$ & $\begin{array}{l}\text { Çelik Ürünleri } \\
\text { Atölyesi Sahibi }\end{array}$ \\
\hline 14. & Celil & 44 & $\begin{array}{l}\text { Lisans } \\
\text { Terk }\end{array}$ & Halep & $6 \mathrm{Ay}$ & Tüccar & $\begin{array}{l}\text { Kafe-Fitness } \\
\text { Salonu- Güzellik } \\
\text { Merkezi Sahibi }\end{array}$ \\
\hline 15. & Naim & 39 & $\begin{array}{l}\text { Yüksek } \\
\text { Lisans }\end{array}$ & Şam & $3 Y_{11}$ & $\begin{array}{l}\text { İletissim Firmasında } \\
\text { Çalışan ve Okutman }\end{array}$ & Poliklinik Sahibi \\
\hline 16. & Cemal & 38 & $\begin{array}{l}\text { Lisans } \\
\text { Terk } \\
\end{array}$ & Halep & $3 Y_{11}$ & $\begin{array}{l}\text { Bilgisayar Ürünleri } \\
\text { Dükkanı Sahibi }\end{array}$ & $\begin{array}{l}\text { Bilgisayar Ürünleri } \\
\text { Dükkanı Sahibi }\end{array}$ \\
\hline 17. & Galip & 40 & Lise & Şam & $4 Y_{11}$ & Tüccar & Market \\
\hline 18. & Malik & 36 & Ortaokul & Halep & $5 Y_{11}$ & Telefon Dükkanı Sahibi & $\begin{array}{l}\text { Telefon Dükkanı } \\
\text { Sahibi }\end{array}$ \\
\hline 19. & Said & 32 & Lise & Halep & $3 Y_{11}$ & Lokantac1 & Lokantac1 \\
\hline 20. & Ziyad & 38 & Ortaokul & Şam & $5 Y_{11}$ & Parfümeri & Parfümeri \\
\hline
\end{tabular}

\section{İşletmelerin Büyüklük, Ortaklık ve Çalışan Yapısı}

Çalışma kapsamında görüşülen işletmelerin çoğunluğu mikro büyüklüktedir. 10 kişiden az çalsşana sahip 15 işletme, 10 ve 10 kişiden fazla çalışana sahip 5 işletme bulunmaktadır. $\mathrm{Bu}$ işletmelerin 3'ünde Suriyeliler yanında Türkler de çalışmaktadır.

Ortaklıklar, göçmen girişimcilerin başka ülkelerdeki işletmelerinde ihtiyaç duydukları maddi manevi desteği sağladığı için büyük önem taşımaktadır. Göçmenler işletme kurma süreçlerinde ortaklık teklifi için ilk olarak aile, akraba ve arkadaşlarına başvurmaktadır. Ortak seçiminde akraba ve aile dışında arkadaşlar arasından da tercih yapılabilmektedir. Mahzar, Celil, Fuad ve Naim, eskiden beri tanıdıkları arkadaşlarını, kendilerine ortak olarak seçtiklerini belirtmişlerdir. Mahzar ortak olarak arkadaşını tercih ederken arkadaşının Türkiye'de bir restoranda şef olarak çalışmasını dikkate almıştır:

“Şam'dan beri arkadaşım olduğu için onunla ortak olmak istedim. O benden önce gelmişti İstanbul'a. O başka bir Suriyeli restoranda şef olarak çalışıyordu Başakşehir'de. Bundan dolayı onunla ortak olmak istedim.” (Mahzar, Şam, 35)

Suriyeli girişimcilerin çalışan profillerinin nasıl olduğu, kaç işçi çalışırıdığı, kimlere daha çok güvendiği ve hemşerilik ilişkilerinin çalışan tercihlerini etkileyip etkilemediği gibi sorular, bu araştırma kapsamında önemsenen konular arasında olmuştur. Suriyeli işletmelerin büyüklügü, müşteri hedef kitlesi, hangi pazarda faaliyet yürüttüğü çalışanlarının sayısını ve kimlerden oluştuğunu etkilemektedir. Etnik arka plana dayalı olarak açılan restoran, lokanta gibi işletmelerde genellikle Suriyeli çalışanların varlığı görülmüştür. Bazı işletmeler ise sadece Suriyelilere hizmet vermediği için diğer ülkelerden ve yerli topluluktan da çalışanlar tercih edebilmektedir. Görüşülen katılımcılar market, bakkal, berber, giyim mağazası gibi tek veya iki kişinin çalışabileceği işletmelere sahip olabildiği gibi atölye, restoran, tıp merkezi gibi daha çok kişinin çalıştı̆̆ işletmelere de sahiptir.

Çalışanların nasıl seçildiği ile ilgili katılımcıların verdiği cevaplar çeşitlilik göstermektedir. Genellikle Suriyelilerin ve diğer Arapların tercih ettiği restoran, parfümeri, market, bakkal, berber gibi işletmelerde ya işletmeci tek başına çalışmakta ya da yanındaki çalışanların neredeyse tamamı Suriyelilerden oluşmaktadır. İşletmenin hizmet verdiği kitle değiştikçe çalşsan yapısı da değişmektedir. Örneğin Fuad, inşaat malzemeleri ihraç ettiği ve Türk firmalarla ilişki içerisinde olması gerektiği şirketinde yerli topluluktan çalışanların da bulunmasını şu şekilde açıklamıştır: 
“7 kişi var. 5’i Türk 2'si Suriyeli çalışanlarımın. Suriyeliler ile daha iyi anlaşıyorum tabii. Türklere bazı durumlarda dilden dolayı ihtiyacım oluyor. Türk firmalarla iletişimde mesela." (Fuad, Halep, 46)

Ancak Suriyelilere yönelik hizmet veren işletmelerde neredeyse bütün çalışanların Suriyeli olduğu görülmektedir. Mevsimsel olarak 18 ile 22 arasında değişen bir çalışan sayısına sahip olan Mahzar, 20 kişi çalıştıran Samir ve 8 kişi çalıştıran Hamza Suriyelilere yönelik hizmet veren restoranları işleten katılımcılardır. Bu katılımcılar işletmelerindeki personelin hepsini Suriyelilerden seçmiştir. Bu işletmelerde Fuad'ın Türk firmalarla kurması gereken bir iletişim gerekliliği bulunmaması bunun bir nedeni olarak görülebilir. İkinci bir neden göçmen girişimcilerin göç edilen ülkede aynı göçmen toplumuna mensup kişilerle dayanışma sergileyerek işe alması ve böylece yerli iş piyasasında zor iş bulan hemşerilerine yardım etmek olarak görülebilir. Bir diğer neden aynı topluluğa mensup olmanın verdiği kültürel ve dil yakınlığ1, daha kolay iletişim kurma ve güven duygusu gibi unsurlar olarak görülebilir.

\section{Farklı Sermaye Biçimlerinin Göçmenlerin Girişimcilik Süreçlerindeki Rolü}

2011 yılında Suriye'de başlayan iç savaş sonrasında Türkiye’ye göç ile gelen dört milyona yakın Suriyeli, Türkiye'nin çeşitli kentlerinde hayatlarını sürdürmektedir. Savaşın uzun süredir devam etmesi Suriyeli göçmenlerin ülkelerine geri dönme umudunu azalmakta ve geleceklerini Türkiye'de kurma ve buraya yerleşme motivasyonlarını güçlendirmektedir. Bu eğilimin etkisiyle, Türkiye'deki göçmen girişimcilik faaliyetlerinde ciddi bir artış gözlenmektedir. Bu çalışmada Suriyeli göçmen girişimcilerin işletme kurma süreçlerinde farklı sermaye biçimlerinin nasıl bir rol oynadığı ortaya konulmaya çalışılmıştır. Çalışma kapsamında Suriye'de 2011 yılında başlayan iç savaş sonrasında Türkiye'ye gelen ve Esenyurt ilçesinde bir işletmeye sahip olan Suriyeli göçmenlere ulaşılmaya çalışılmıştır. Yapılan saha araştırması ile göçmenlerin farklı sermaye biçimlerinin oranları farklı olmakla birlikte işletme kurma süreçlerinde önemli bir rol oynadığ1 ortaya çıkmıştır.

Çalışmada göçmenlerin ekonomik, sosyal ve kültürel sermaye biçimlerini girişimcilik süreçlerinde kullanma yolları, her bir sermaye biçiminin işletme kuruluşunda nasıl bir etkisinin olduğu ortaya konmuştur. Buna göre işletme kurmada kilit öneme sahip olan ekonomik sermayeyi göçmenlerin bir kısmı Suriye’den kendisi ile birlikte getirerek, bir kısmı ücretli bir işte çalışıp biriktirerek, diğer bir kısmı ise akraba, arkadaş, hemşeri gibi yakınlardan borç alarak temin etmiştir. Göçmenler işletmenin hangi tipte, nerede, nasıl olacağ1 ile ilgili bilgileri sosyal sermayeleri aracıllı̆̆ ile edinmişlerdir. Bunun yanında yeterince parası bulunmayan göçmenler yine bu sermayeleri sayesinde işletme kurmak için gerekli borç parayı bulabilmiştir. Göçmenler bir diğer sermaye biçimi olan kültürel sermayeyi işletme kurma süreçlerinde kullanmada farklı yöntemler oluşturmuştur. İlk olarak bazı göçmenler anavatandan edindikleri diploma, sertifika gibi belgeleri Türkiye'de kabul ettirerek işletme kurmada bu belgelerini kullanmışlardır. İkinci olarak göçmenlerin büyük kısmı ulusal veya göç edilen ülke arka planı temelinde işletmeler kurmuşlardır. Üçüncü ve son olarak, anavatandan sahip olunan kişisel beceri ve yetenekleri işletme kurmada kullanan bir kısım bulunmaktadır.

Esenyurt'ta girişimcilik faaliyetinde bulunan Suriyeli göçmenlerin büyük bölümü savaştan kaçarak gelirken biriktirdikleri maddi varlıkların nakledilebilecek kısmını kendileriyle birlikte Türkiye'ye getirmiştir. Ancak ev, araba, arsa, daha önceki işletmelerinde var olan makine ve teçhizatın büyük bir kısmını nakit paraya dönüştürememişlerdir. Suriye'deki savaşın kısa sürede biteceğini düşünen birçok katılımcı ilk başta ne bir işe girdiklerini ne de bir iş kurmayı

Göç Dergisi 
düşündüklerini belirtmiştir. Bu süre zarfinda var olan ekonomik birikimlerini harcayarak yaşamlarını devam etmişlerdir:

"Aslında savaş sürmesine rağmen çıkmadık şehirden. Ama bir bomba yakınıma isabet edip ben yaralanınca çıkmaya karar verdik. Bacağımdan yaralandım, bacağımı ameliyat ettirdikten sonra çıktık Halep'ten. Yasal bir şekilde pasaportla geldim Türkiye'ye. Bütün aileyle birlikte geldim. İlk başta üç aylığına çıktık sonra dönmeyi düşünüyorduk. Önce Hatay Reyhanlı'da bir ev aldım. 3 ay sonra döneceğimi düşünmüştüm ama öyle olmadı. (...) Hatay Reyhanlı'da, Konya'da kaldım buraya gelmeden önce. $\mathrm{O}$ şehirlerde herhangi bir işte çalışmadım. Sadece dönmeyi bekledim. (...) Para getirdim buraya ama 5 yıl çalışmadım. O parayı harcadım. (...) 2014'te, 4 sene önce vatandaşlı̆̆ aldık. Sonra beklemeye devam ettik savaşın bitmesini. Suriye'ye döneceğiz diye bekledik hep. İş kurmayı düşündüğümüz için değil, sadece akrabalarımız olduğu için geldik İstanbul'a.” (Fuad, Halep, 46)

“(...) Üç yıl boyunca Suriye’den getirdiğimiz paramızı harcadık. Bu sürede savaşın bitmesini bekledik." (Ahmet, Halep, 31)

Savaşın kısa sürede bitmeyeceğinin anlaşılmasıyla Suriyeli göçmenlerin iş kurma motivasyonları güçlenmiş ve bazı göçmenler Suriye'de biriktirdikleri ekonomik sermayeyle Türkiye'de işletme açmaya başlamışlardır:

"500 bin dolar nakit para getirdik. 200 bin dolar atölyeyi kurmak için harcadık. 100 bin dolar Kahramanmaraş’ta harcadık. Kalanını harcamadık.” (Ahmet, Halep, 31)

“Hepsini getiremedim. Emlaklar kaldı Suriye’de ve Suudi Arabistan'da. Onları satıp buraya getirdiğimde zarar ederim. Dolar çok yüksek. 3 milyon dolar getirdim buraya yatırım yapmak için. Banka aracıllğıyla getirdim ama yavaş yavaş getirdim." (Celil, Halep, 44)

Suriye'den getirdiği yeterli bir ekonomik birikimi olmayan veya olan birikimini Suriye'deki savaşın bitmesini beklerken harcayan göçmenler ise bir işe girip, para biriktirerek işletmelerini kurmuşlardır. Örneğin Abdullah işletmesini kurmadan önce çalışarak para biriktirdiğini ve böylece işletme kurabilecek sermayeyi elde ettiğini belirtmiştir:

"Eniştem vardı Kahramanmaraş’ta. Onun yanında iki yıl kaldım. Oradayken çelik çaydanlık, tencere işinde çalıştım. Kahramanmaraş'ta çalıştığımda 17 bin TL biriktirdim. Sonra İstanbul'da çalışarak 6 bin TL biriktirdim. Bir kişi ile ortaklık yaptım ve burayı açtım.” (Abdullah, Halep, 21)

Bir işletmenin açılmasında gerekli olan en önemli unsurlardan biri olan ekonomik kaynakların varlığ1 göçmenlerin işletme kurma süreçlerinde de önemli bir role sahiptir. Suriye'den getirebilecek ekonomik sermayesi düşük olan ya da hiç olmayan göçmenler genellikle daha düşük kapasiteli işletmeler açmıştır. Ekonomik sermayeleri güçlü olan ve bu sermayelerini Türkiye'ye aktarabilen göçmenler ise daha büyük işletmeler açabilmiştir.

“Toplumsal yükümlülüklerden (bağlantılar) oluşan, belirli şartlar içinde ekonomik sermayeye çevrilebilir ve bir soyluluk unvanı gibi biçimlerde kurumsallaştırılabilir” (Bourdieu 2010: 49) sermaye olarak nitelenen sosyal sermaye göçmenlerin göç öncesinde, esnasında ve sonrasında kullandığ1 sosyal ağlarla şekillenen bir toplumsal ilişkiler bütünü veya toplam değeri olarak düşünülebilir. Suriye'den Türkiye'ye ilk gelen göçmenlerin büyük kısmı bu sosyal ağ ve sermayeden yoksun bir şekilde yaşamış, ancak bu ilk gelen grupların öncülüğünde oluşan ağlar ve ilişkiler büyük kentlerin bazı semtlerinde göçmenlerin yoğunlaştığı kümeler yaratmaya 
başlamıştır. Daha sonra göç ile gelenlerin kent içinde nerede ikamet edeceğinde bu ağların ve ilişkilerin büyük rolü olmuştur. Özellikle aile, akraba, arkadaş, tanıdık ve hemşeri ilişkileri ile var olan bu ağlar göçmenlerin iş kurma süreçlerinde önemli etkilere sahiptir. Karşllıklı yükümlülük ilkesine dayanan sosyal sermaye kavramı göçmenlerin hayatlarının birçok alanında işlerlik kazandığı gibi ekonomik alanda da işlevli bir konuma sahiptir.

Esenyurt'ta görüşülen Suriyeli göçmen girişimcilerin büyük kısmı işletme kurma süreçlerinde aile, akraba, arkadaş veya hemşeri yardımına başvurduğunu ve bu yardımın maddi veya manevi olarak gerçekleştiğini aktarmışlardır. Yeni gelinen ülkede işletme açma süreçleriyle ilgili bilgiler göçmenlere tanıdıkları aracılığıyla aktarılmıştır. Örneğin Celil akrabalarının daha önce göç etmesinden kaynaklı kendisinden daha fazla bilgiye sahip olduklarını ve manevi olarak kendisini desteklediklerini şu ifadelerle anlatmıstır:

"Manevi olarak yardım edenler oldu. Yeğenlerim, abim, eski arkadaşlarım yardım ettiler bana. Onlar 4-5 yıl önce buraya geldikleri için benden daha iyi biliyorlardı her şeyi. Savaş başladığında buraya geldiler." (Celil, Halep, 44)

İşletme kurma sürecinde tanıdıkların göçmenlere yardımı hangi işletmenin nerede kurulacağ1 ile ilgili tavsiyeleri de içermektedir. Mahzar ve Abdullah arkadaşlarının önerisiyle işletmelerini açtıklarını şu ifadelerle belirtmişlerdir:

“Arkadaşlarımla konuşuyordum. Arkadaşlarım burayı önerdiler. İşletmeyi burada kurmamın sebebi de Suriyelilerin burada daha çok olmasıydı. Bir de buradaki (Esenyurt) dükkân kiraları İstanbul'un diğer semtlerine göre daha ucuz olduğu için burayı tercih ettim.” (Mahzar, Şam, 35)

“Dükkânı Türk bir işletmeciden devraldım. 2015 yılında başladım bu işe. Merter'de çok fazla arkadaşım vardı. Onlara sordum nasıl bir iş yapabilirim diye. Sonra Merter'de bir giyim mağazasında 2 hafta çalıştım. Sonra bu işi yapmaya karar verdim. İlk ürünlerimi de Merter'deki tanıdıklarımdan aldım.” (Abdullah, Halep, 21)

Yukarıdaki işletme açma durumlarında doğrudan parasal bir destek olmamakla birlikte girişimcilerin tanıdıkları hangi işletmenin nerede ve nasıl kurulacağı ile ilgili destek sağlamıştır. $\mathrm{Bu}$ anlamda göçmenler arasındaki özellikle göç ile gelinen ülkedeki dayanışma ağları göçmenlerin girişimcilik faaliyetlerinde etkin bir konuma sahiptir. Bu örnekler dışında göçmenlerin işletme açma süreçlerinde yakınlarından parasal destek de aldığ1 görülmektedir. Suriyeli göçmenler bankalardan kredi sağlayamadıklarını bundan dolayı yakın çevrelerinden parasal ihtiyaçlarını karşılamaya çalıştıklarını belirtmektedir. Göçmenler işletmeyi kurma süreçlerinde yakınlarından parasal olarak aldıkları destekleri şu şekilde aktarmıştır:

"Suudi Arabistanlı bir arkadaştan 3 bin dolar borç aldım. O İstanbul'a geldiğinde yardımcı olmuştum birkaç konuda. Ev falan buldum ona. Öyle arkadaş olmuştuk. O yardım etti. Bir yıl içinde ödedim borcumu. Şirket adına bankadan kredi çekebilirdim ama şirket yeni olduğu için vermezlerdi. Başkasından aldığım için şirketin vergi borcu da vardı.” (Abdullah, Halep, 21)

"Ailemden 10 bin dolar borç aldım iş için. Onu da ödedim. Onun dışında kimseye ihtiyacım olmadı. Ama başkalarının bana ihtiyacı oldu ben onlara borç para verdim. İnsanlara çok yardımcı olduğumuz için hastane konusunda, onlar da bize yardım etmek istiyorlar. Bana doktor gözüyle bakıyorlar." (Naim, Şam, 39) 
Suriye'den Türkiye'ye göç eden Esenyurt'taki girişimciler kültürel sermayelerini ekonomik sermayeye tahvil etme konusunda farklılaşan yollar oluşturmuştur. Birinci yol, Suriye'de kazandıkları diplomaların Türkiye'de kullanabilmesiyle mümkün olmaktadır. Suriye'den edinilen diplomalarını Türkiye'de kullanarak girişimcilik faaliyetlerinde bulunan küçük bir grup bulunmaktadır. Bu yolla girişimcilik faaliyetinde bulunanlara örnek olarak Fuad verilebilir. Suriye'de inşaat mühendisliğinden mezun olmuş ve Suriye'nin çeşitli şehirlerinde çalışmış sonrasında savaş sırasında Türkiye’ye göç etmek zorunda kalmış olan Fuad mesleği ile ilgili şu bilgileri vermiştir:

“İnşaat mühendisiydim. İnşaat sektöründe çalışıyordum. Sanayi bölgelerinde çalıştım. Konut yaptık. Çelik konstrüksiyon üzerine çalıştık yani. Daha çok Halep, Şam ve Rakka şehirlerinde çalıştım.” (Fuad, Halep, 46)

Türkiye'ye göç ettikten sonra uzun süre savaşın bitmesini bekleyen Fuad, İstanbul'a geldikten sonra bir inşaat şirketinde çalışmaya karar vermiştir. Öncesinde Suriye'ye geri dönme umudu güçlü olduğu için herhangi bir işte çalışmayı düşünmeyen Fuad, ekonomik birikimini de bu çalışmadığı süre zarfında harcamıştır. Mühendis olarak bir firmada çalışmasını şu şekilde aktarmıştır:

"Orada [firmada] işimde ustaydım. Sabahtan akşama kadar çalışıyordum bilgisayarımla. Alman gibi çalışıyordum. O yüzden ortağım gelip bir şirket kurmayı teklif etti. Sermayeyi o getirdi." (Fuad, Halep, 46)

Fuad, Suriye'de kazandığı meslek bilgisi ve diploması sayesinde ortaklarına oranla daha az bir parayla işletme kurabilmiştir. Bu örnekte olduğu gibi belirli şartlarda kültürel sermaye ekonomik sermayeye dönüştürülme imkânına sahip olabilmektedir.

Esenyurt'ta Suriyelilerin kültürel sermayeyi ekonomik sermayeye çevirmesinin ikinci yolu ise ulusal veya göç edilen ülke arka planı temelinde Suriyeli ve diğer Arap ülkelerinden insanların beğeni ve ihtiyaçlarına yönelik işletmeler kurulmasıdır. Göçmenler göç ile geldikleri ülkede yerli dili bilmeme, iş piyasasındaki ayrımcılık, meslek ve eğitim ile ilgili belgeleri kabul ettirememe gibi nedenlerden dolayı daha kolay bir yol olarak kabul edilebilecek etnik veya göç edilen ülke arka planına yaslanma stratejisini seçebilmektedir (Akis-Kalaylığlu, 2016: 155). Suriyeli yoğun bir nüfusun yaşadığ1 Esenyurt bölgesinde görüşme yapılan katılımcıların büyük kısmı bu yolu takip ederek işletme kurmuşlardır. Yemek sektöründe işletme açan girişimcilerden biri olan Samir, işletmesini açma gerekçesini, Suriye yemeklerinin Türkiye yemeklerine göre farklılıklarını ve göçmen topluluğuna mensubiyetini ön plana çıkararak açıklamaktadır:

"Esenyurt'ta Suriyeli ilk restoranı aile olarak biz açtık. Bizim yemeklerimiz Türk yemeklerine göre çok baharatlı ve yağlı. Suriyeliler çok fazlaydı Esenyurt'ta. Bizim restorana geliyorlard1 hep. Suriyeli olduğumuz için dil sorunu da yaşamıyorlardı.(...) Suriye'de de restoran işindeydik. Restoran çok lazım bir şey. Parası olan da olmayan da yemek yemek zorunda. Suriyeliler burada çoktu ama hiç Suriye yemekleri yapan restoran yoktu. O yüzden burayı açtık. Esenyurt Köyiçi'nde de bir şubemiz var.” (Samir, Şam, 29)

Katılımcının ifadesinde belirttiği gibi Suriyeli göçmenler etnik veya ülke arka planlarına yaslanarak Suriyeli nüfusun yoğun olduğu Esenyurt'ta bu gruba yönelik işletmeler açarak yerli topluluktan kültürel olarak farklılıklarını bir avantaja dönüştürüp ekonomik kazanç sağlamaktadırlar. 


\section{Türkiye'deki Suriyeli Gösmenlerin Girişimcilik. Faaliyetlerinde Farkh Sermaye Biçimlerinin Rolü}

Bu iki yolun dışında bazı katılımcılar ise bir üçüncü yol ile kültürel sermayeyi ekonomik sermayeye çevirme yöntemi geliştirmiştir. Bu üçüncü kesim ne etnik arka planına dayanarak ne de Suriye'de edindikleri diplomalar aracilığıyla işletme kurmuşlardır. Bu işletmeciler Suriye'de edindikleri yetenek, bilgi ve becerilerini kullanarak sadece Suriyeli göçmenlere değil aynı zamanda yerli topluluğa yönelik olarak da girişimcilik faaliyetlerinde bulunmaktadır. Örneğin Mahir'in Suriye'de öğrenci iken kozmetik sektöründe çalışarak kazandığ1 mesleki bilgisi iş kurma sürecinde etkili olmuştur. Tecrübesi sayesinde düşük bir ekonomik sermaye ile normal şartlarda ortak olamayacağı bir işletmenin ortağı durumuna gelmiştir :

“İki buçuk yıl önce burayı açtım. Halep’ten bir arkadaşım vardı. Türkiye’ye ilk geldiğinde tekstilde çalıştı o. Beğenmedi maaşları. elli bin TL civarında bir parası vardı. Arkadaşımın abileri Halep’ten gönderdiler ona. Arkadaşımda sermaye vardı, bende de uzmanlık. İlk başta çok iş yapamıyorduk. Sonra yavaş yavaş iyileşti satışlar. (...) Şirketi kurmayla daha çok ortağım uğraştı. Ama uzmanlık bilen bendim. Sonra birlikte kurduğum arkadaşım hissesini Şamlı bir Suriyeliye sattı. Yeni ortağım olan Suriye'de mühendislik yapmış yaşlı biri. Bir market açacaktı Türkiye’ye geldiğinde. İşyeri ararken bir emlakçı buraya yönlendirdi onu. Daha ortağım bırakmamıştı. İlk ortağım bıraktı, yeni ortağımla çalışmaya başladık. Ben çok fazla para koymadım. Sermayem tecrübemdi.” (Mahir, Halep, 24)

Mahir gibi Ahmet de Suriye'de kazandığı bilgi ve beceri sayesinde işletme kurabilmiştir. Ahmet mekanik mühendisi olan babasının yanında lise çağlanından itibaren edindiği beceri ve bilgi sayesinde çelik mutfak aletlerinde yetkinleşmiş ve ifadesine göre göç süreciyle birlikte Suriye’de erişemediği maddelere de ulaşarak mesleğinde daha da güçlenmiştir:

"Üç yıl boyunca Suriye'den getirdiğimiz paramızı harcadık. Bu sürede savaşın bitmesini bekledik. Kardeşim Türkçe kursuna gidip Türkçeyi öğrendi. Ben de bir dükkân kiralayıp kaynak işini biraz geliştirdim. Küçük metal zücaciye malzemeleri ürettim. Buradaki ham maddeler Suriye'de yoktu. Bu yüzden daha farklı şeyler yapabiliyordum. Suriye'de olmayan Türkiye'de olan ham maddelerle kaynak işini çok fazla geliştirdim.” (Ahmet, Halep, 31)

Öyle ki anlatımına göre yerli firmaların bilmediği yöntemlere sahip olmasıyla birçok ürünü daha ucuza mal edebilmekte ve büyük firmalara satmaktadır:

"Suriye'de babamın yanında çalışıyordum. Babam mekanik mühendisi. O eğitti beni. Babam benim üniversitem. Suriye'de fabrikalarımızda bazı meslek sırlarımız vardı. Aile dışından biri sırrımızı öğrenmesin diye kendimiz çalıştık hep. O yüzden okumak yerine babamın yanında çalıştım. (...) Sonra çelik mutfak eşyalarının imalatı işini yapmaya başlamış babam. 70 kişi çalışıyordu bu imalathanede. Ben de bu işte çalışıyordum, babamın yanında. Yaptığımız ürünleri Cezayir, Ürdün, Suudi Arabistan ve Irak'a ihraç ediyorduk. (...) İstanbul'a geldiğimizde Korkmaz, OMS gibi maden mutfak firmalarılyla ilişki kurduk. Türkiye'de paslanmaz çelikte sadece kalın tabakaya şekil verebiliyorlar, ince kalıba şekil veremiyorlar. Yapamıyorlar. Türkler ince yapmaya çalıştığında kırılıyor. Ama biz yapabiliyoruz. Bizim kendi özel sistemimiz var. Bu yüzden bizim maliyetimiz Türklerden daha az. Bu yüzden ucuza satabiliyoruz. Araplar Türklerden almıyordu önceden. Ama artık bizim imalatımızı alıyorlar. Ve biz Türklerden daha ucuza satıyoruz. Biz direkt onlara (Araplara) satmıyoruz. Biz OMS firmasına satıyoruz, o gönderiyor. İlişkilerimiz olmadığ1 için büyük bir firma aracılık yapiyor."(Ahmet, Halep, 31) 
Bu ifadelerden de anlaşılacağı üzere Ahmet, Suriye'de kazandığı bilgi ve becerileri sayesinde Türkiye'de kültürel kimliğine veya bir eğitim belgesine ihtiyaç duymaksızın bir işletme açabilmiş ve böylece kültürel sermayesini ekonomik sermayeye dönüştürebilmiştir.

\section{Farklı Sermaye Biçimlerinin Göç ile Gelinen Ülkeye Transferi}

2011 yllında başlayan Suriye iç savaşı ile birlikte göç süreçlerine dahil olup Esenyurt bölgesinde girişimcilik faaliyetlerinde bulunan Suriyeli göçmenlerin ekonomik, sosyal ve kültürel sermayelerini Türkiye’ye ve yeni hayatlarına nasıl transfer ettikleri göçmenlerin girişimcilik süreçlerinin anlaşılması açısından önemlidir. Faist'e göre sermaye biçimleri içerisinde "en kolay nakledilebilir olan ekonomik sermayedir" (Faist, 2003: 46). Kültürel sermayenin ise başka bir ülkeye transferi daha zor olmaktadır. Eğitim kurumlarından alınan sertifika ve belgeler göç edilen ülke tarafından tanınmayabilir ve göç edilen ülkede iş sahibi olabilmek için göçmenlerin yeni ülkenin dilini öğrenip tekrar eğitim alması gerekebilir. Başka bir ülkeye aktarılması en zor olan sermaye türü ise sosyal sermayedir. Sermaye türleri içinde mekâna özgü tek sermaye, sosyal sermaye olmaktadır (Faist, 2003: 46). Ancak kitlesel ve zincirleme göç durumlarında sosyal sermaye başka bir ülkeye taşınabilir olmaktadır (Faist, 2003: 41).

Dünya örneklerinde karşıllğ̆nda teminat olarak gösterilebilecek sabit varlık göstermekte zorluk yaşayan göçmenlerin işletme kurmak için kredi sağlamaları güçleşmektedir (Sunata, 2018: 175). Bu durum Türkiye'deki Suriyeli göçmen girişimciler için de geçerlidir. Suriyeli göçmenler Türkiye'deki statülerinden kaynaklı ve teminat olarak sabit varlık gösterememelerinden dolayı bankalardan kredi alamadığı için Suriye'den getirdikleri ekonomik sermayeleri işletme açmaları için zorunlu olabilmektedir. Görüşülen göçmenler göç sürecinde yanlarına alabildikleri maddi varlıklarla Türkiye'ye geldiklerini belirtmiştir. Suriye'deki ev, arsa, araba, dükkan gibi varlıklarını nakite dönüştürerek göç eden katılımcılar olduğu gibi Suriye'deki mallarını nakite dönüştüremeyen veya evleri savaş sırasında yıkılmış katılımcılar da mevcuttur:

“Evim vard1 yıkıldı savaşta. Zaten Suriye'de de çok param yoktu. Bende Suriye parası vardı. Dolar yükselince elimdeki paranın da pek değeri kalmadı. Döviz yaptım ve buraya geldim. 10 bin dolar civarında param vardı Türkiye'ye geldiğimde.” (Naim, Şam, 29)

Katılımcılar nakite dönüştürdükleri varlıklarını yanlarında getirebilirken buna karşın Suriye'de kalan ve değerinden çok düşük fiyata gideceğini düşündükleri için satmadıkları mülkler de bulunmaktadir.

"Evet, nakit paramı getirdim. Ama topraklarım var, dairem var, arsam var orada satılamaz da bu durumda. Savaştan 1 ay önce Halep'te ev aldım ben. Fiyat1 400 bin dolar.” (Fuad, Halep, 46)

Ekonomik sermaye kadar kolay bir şekilde başka bir ülkeye transfer edilemeyen kültürel sermaye, göçmenlerin yeni ülkede yapacağı mesleği ve buna bağlı olarak elde edeceği statüyü belirleyen etkenlerin başında gelir. Göç süreçlerinde göçmenler göç ettikleri ülkelerde beceri, yetenek ve eğitimlerini kabul ettirmek için büyük çaba harcamaktadırlar. Göçmenlerin menşe ülkede eğitim kurumları aracıllğıyla elde ettikleri sertifika, diploma vb. belgeler çoğu zaman hedef ülke otoriteleri tarafindan geçerli sayılmamaktadır. Bu durum göçmenlerin uzun yıllar sonunda elde ettikleri kültürel sermayelerini bir anda değersiz bir hale getirmektedir. Göç ile gelinen ülkenin yasal koşulları ve göçmen politikalarına ve göçmenin yeni ülkedeki statüsüne göre kaynak ülkeden alınmış bu belgelerin tanınıp tanınmayacağına karar verilmektedir. Yani 


\section{Türkiye'deki Suriyeli Gösmenlerin Girişimcilik. Faaliyetlerinde Farkh Sermaye Biçimlerinin Rolü}

göç edilen ülke göçmenin kurumsallaşmış kültürel sermayesi olan örneğin diplomasını tanırsa göçmenin bu diplomayla -yerli adaylarla eşit olmayan bir şekilde olsa bile- bir iş bulma olasıllı̣̆ bulunmaktadır. Türkiye'deki Suriyeliler örneğinde çeşitli olumlu çabalar olsa dahi saha araştırması sırasında birçok yüksek öğrenim görmüş veya Suriye'de iyi bir mesleğe sahip göçmen Türkiye'de sertifika ve belgeleri tanınmadığı için vasıfsız işlerde ve düşük bir ücret karşılığ1 çalışmaktadır.

Esenyurt'taki Suriyeli girişimcilerin kültürel sermayeyi transfer etme durumlarına bakıldığında genel olarak dünyada var olan eğilimle örtüştüğü görülmektedir. Göçmenlerin Suriye’de aldığ1 diploma ve belgelerin birçoğu Türkiye'de tanınmamaktadır. Yapılan saha araştırması kapsamında görüşülen katılımcıların bazıları üniversite mezunu veya üniversiteyi terk etmiş durumdadır. Inşaat mühendisi olan ve 2014 y1lindan beri Türk vatandaşı olan Fuad Türkiye'deki bir inşaat firmasında çalıştıktan sonra yurtdışına inşaat malzemeleri satan bir şirkete ortak olmuştur. Bu örnekte Türkiye vatandaşı olmasının da olumlu etkisiyle Fuad Suriye'de edindiği diplomayı Türkiye'de tanıtabilmiş ve hem bir şirkette iş bulmuş hem de sonrasinda kendi şirketini kurmuştur. Burada kültürel sermayenin ekonomik sermayeye dönüştürülmesi görülmektedir.

Buna karşın daha önce Suriye'de bir üniversitede Arapça okutmanı olan Hamit Hatay'da düşük bir ücret karşılı̆̆1 Suriyelilere Arapça eğitim vermiş ancak bunun dışında mesleği ile ilgili bir pozisyonda iş bulamamıştır. Bunun yerine etnik ve göçmen arka planını kullanarak Suriyeliler ve Arapların ilgi gösterdiği bir kargo firması kurmuştur. Mahir ve Samir ise üniversite eğitimini Suriye'de savaş başlayınca yarıda bırakmak zorunda kalmışlardır. Samir eğitimine Türkiye'de devam etmek istese de işletme açtığını ve geçimini sağlamak için çalışması gerektiğini belirtmiştir. Mahir ünversiteye devam ederken çalıştı̆̆1 ve bilgi edindiği kozmetik işiyle alakalı olarak Esenyurt'ta bir işletmeye ortak olmuştur. Yusuf Suriye’de kamyon şoförlüğü, Velid ise taksi şoförlüğü yapmaktayken Türkiye'de sürücü belgeleri tanınmadığ1 ve Türkçeye hakim olmadıkları için mesleklerini yapamadıkları görülmektedir. Suriyeli göçmenlerin Türkiye’de araç kullanabilmek için sürücü kursuna giderek tekrar sürücü belgesi edinmeleri gerekmektedir. Bu iki göçmen kendi meslekleri dışında kendi göçmen topluluklarına yönelik hizmet sektöründe işletme açmışlardır.

Görüldüğü gibi göç süreçlerinde kaynak ülkede kazanılan diploma ve sertifikalar çoğu durumda iyi bir iş sağlamak için yeterli olamamaktadır. Bu durumlarda göçmenler kendi göçmen topluluğuna yönelik işletmeler açarak dezavantajlı durumlarını avantaja çevirebilmektedir. Görüşme yapılan katılımcıların çoğu bu gruba dahildir.

Sosyal sermaye daha önce de ifade edildiği gibi transferi en zor sermaye biçimidir. Ancak kitlesel ve zincirlemesine göç süreçlerinde sosyal sermayenin başka bir ülkeye transferi münkün olabilmektedir. Türkiye'ye ilk göç eden Suriyeli göçmenlerin başta sınırdaki illerde daha sonrasında Türkiye'nin İstanbul, İzmir gibi büyük şehirlerinde oluşturdukları sosyal ilişki ve ağlar ve bununla bağlantılı olarak bazı semtlerde yoğunlaşmaları Suriyeden yeni gelen göçmenlerin göçün nasıl yapılacağı, hangi ile göç edileceği, barınma, iş bulma gibi konularda istifade edebilecekleri bir kaynağın oluşmasını sağlamıştır. Göçmenler akraba, arkadaş ve tanıdıklarını takip ederek kentlerin bazı ilçe ve mahallelerinde yoğunlaşmaya başlamıştır. Esenyurt'taki Suriyeli girişimciler de sosyal ilişki ve ağlarının bu bölgeye gelmelerinde etkili olduğunu görülmüştür. Kitlesel olarak yaşanan Suriye göçü sonrasında Türkiye'ye resmi kayıtlara göre dört milyona yakın Suriyeli göç etmiştir. Böyle kitlesel bir göç sonucu ortaya çıkan göçmen yoğun semt ve mahalleler bazen Suriye'nin bir mahallesinden veya köyünden 
olanların yoğunlaştığı durumlar yaratmaktadır. Türkiye'nin farklı illerinde yapılan bazı araştırmalar Türkiye'deki Suriyelilerin büyük çoğunluğunun Halep kentinden geldiğini göstermektedir (Kaya, 2017: 46; Gültekin vd., 2018: 7; Çetin, 2016: 203). Bu durumda Halep'in Türkiye'nin sınır bölgesindeki iller ile tarihi, siyasi, sosyal ve ticari ilişkilerinin etkisi bulunmaktadır. Esenyurt'ta da görüşme yapılan girişimcilerin çoğunluğu Halep’ten geldiğini ifade etmektedir. Suriye'nin diğer şehirlerinden gelen katılımcılar da Esenyurt'ta Haleplilerin yoğun olduğunu belirtmiştir:

"Akrabalarımla bayramda sahile gidiyoruz. Yeni tanıştığım çok kişi var. Buradaki Suriyelilerin çoğu Halepli.” (Mahir, Şam, 24)

"Burada kimseyi tanımıyorum. Akrabalarım çok yok burada. Esenyurt'taki Suriyelilerin \%00”1 Halepli. Ben Şamlıyım. O yüzden çok kişi tanımlıyorum.” (Hamza, Şam, 34)

Göç edilen ülkede aynı mahalleden hatta aynı şehirden olmak göçmenler arasında daha yakın ilişkilerin gelişmesine yardımcı olabilmektedir. "Yeni bir yere yerleşme hem ulusal hem de uluslararası göç sürecinde belli şartlar altında insanların bölgesel ve etnik ağlarının (hemşehrilik) sıkılaşmasına yol açmaktadır" (Erbaş, 2019: 80). Katılımcıların çoğu boş zamanlarında aile ve akrabalarıyla zaman geçirdiklerini belirtmiştir. Suriyelilerin Türkçe dilini iyi bilmeme, ayrımcıllk gibi nedenlerle daha çok Suriyelilerle ilişki kurdukları görülmektedir. $\mathrm{Bu}$ durum işletme kurma ve ortak seçiminde de etkili olmakta ve Suriyeliler çoğunlukla Suriyelilerle ortak olmaktadır. Bazı katılımcılar ortaklarını Suriye'den tanıdıkları akraba ve arkadaşlanından seçişlerini ve nedenlerini "İki ortağım var, ikisi de akrabam. (Hamza, Şam, 34), "Hem akrabam olmasi hem de daha iyi anlaşabileceğim için Suriyeli biriyle ortak oldum. (Yusuf, Halep, 38)" ifadeleri ile açıklamıştır. Bunun yanında Suriye'de hiç tanışmamışken Türkiye'de arkadaşlık geliştirerek işletme kuran Suriyeliler de mevcuttur. Örneğin Hamalı olan Hamit, kargo şirketini açarken Şamlı bir arkadaşı ile ortaklık kurmuştur. Buradan hareketle Suriyeli girişimcilerin sosyal ilişki ve ağlarını önemsediklerini ve ortak seçiminde dikkat ettikleri anlaşılmaktadır.

Esenyurt'taki Suriyeli göçmenlerin sosyal sermayelerini Türkiye'ye transfer etmede ve karşl1ıklı yükümlülükleri devam ettirme açısından çoğunlukla başarılı oldukları söylenebilir. Ancak göçün ağır koşulları dolayısıyla sosyal sermayelerinde kayıpları olan girişimciler de bulunmaktadir.

\section{Sonuç}

Araştırmanın temel sorunsalı farklı sermaye biçimlerinin Türkiye'deki Suriyeli göçmenlerin girişimcilik faaliyetlerinde nasıl bir rol oynadığıdır. Saha araştırmaları sonucunda ekonomik, sosyal ve kültürel sermayenin göçmenlerin girişimcilik faaliyetlerinde çeşitli oranlarda rolü olduğu görülmektedir. İç savaşın biteceğine dair göçün ilk yıllarında devam eden umut, göçmenlerin ekonomik birikimlerinin bir kısmını harcamalarına sebep olmuştur. Bu süreçte savaşın bitmesini bekleyen göçmenlerin büyük çoğunluğu işletme kurmayı düşünmemiştir. Ancak savaşın sürmesi ve kısa-orta vadede barış ve huzur ortamının oluşturulmasının çok zor olduğu gerçeği göçmenler arasında işletme kurma motivasyonunu arttırmıştır.

Ekonomik sermaye, bir ülkeden başka bir ülkeye transferi diğer sermaye türlerine göre en kolay olanıdır. Ekonomik sermayesini Suriye'den Türkiye’ye taşıyan göçmenler, diğer göçmenlere göre işletme kurma süreçlerinde daha az sorunla karşılaşmıştır. Ekonomik sermayesi düşük olan veya hiç birikimi olmayan göçmenler ise işletme kurmak için ilk yıllarda 


\section{Türkiye'deki Suriyeli Göcmenlerin Girişimcilik. Faaliyetlerinde Farkh Sermaye Biçimlerinin Rolü}

çeşitli işlerde çalışarak para biriktirmiştir. Bu anlamda ekonomik sermayenin işletme kurma süreçlerinde göçmenler için en önemli sermaye biçimi olduğu ve diğer sermaye biçimlerinin ekonomik sermayeye dönüştürülebildiği sürece girişimciler için işletme kurma ve sürdürme süreçlerinde değerli olduğu anlaşılmaktadır.

Sosyal sermaye mekânla ilişkisi en yoğun sermaye türüdür. Oluştuğu ortamdaki ilişkiler ve mekân sosyal sermayeyi yaşatan ve sürekli kılan unsurlardır. Göç süreçleri kitlesel veya zincirleme göç halini almadığ1 durumlarda sosyal sermayenin bir ülkeden başka bir ülkeye taşınması hayli güçtür. Ancak Suriye göçü bağlamında bakıldığında bazı durumlarda bir ailenin, bir sülalenin veya bir mahallenin göç sürecinde birlikte hareket etmeleri, parçalı olarak göç ettiklerinde ise sonradan gelenlerin ilk gidenleri takip etmesi sonucu menşe ülkedeki ilişki ve yükümlülüklerin yeni gelinen ülkeye taşınabildiği görülmektedir (Faist, 2003: 41-46). Bunun yanında göçmenlerin kentlerin bazı mahalle ve semtlerinde yoğunlaşması, Suriye'de birbiriyle belki de hiç karşılaşmayacak Suriye'nin farklı şehirlerinden insanlar arasında hemşerilik ve güven duygusuyla kurulan diasporik yakınlıklar oluşturmaktadır. Diğer yandan göçmenlerin yerli topluluktan insanlarla kurduğu arkadaşlık ilişkileri de göçmenlerin yeni ülkedeki ağına dahil olmaktadır. Yani hem göç öncesinde tanıdı̆̆ı akraba, arkadaş ve mahalleli ile aynı semte yerleşip ilişkilerini sürdürmesi hem göç ettiği ülkenin başka şehirlerinden insanlarla yeni yerleştiği ülkede tanışması, yakınlaşması hem de yerli topluluktan kişilerle arkadaşlık ilişkisi geliştirmesi, göçmen için üç katmanlı bir sosyal ağ kurmaktadır. Bu katmanların yoğunluğu ve sosyal sermaye olarak gücü aynı olmamakla beraber birlikte kullanıldığında çarpan etkisine sahip olabilmektedir. İşte bu ağlar üzerinde var olan sosyal sermaye göçmenlerin girişimcilik faaliyetlerinde önemli bir rol oynamaktadır. İlk olarak göçmenler işletmelerini nerede kuracakları, hangi sektörde işletme açacakları, hukuki gereklilikler gibi konularda akraba ve tanıdıklarından bilgi ve tecrübe desteği alabilmektedir. İkinci olarak yeni gelinen ülkede yeterince ekonomik birikime sahip olmayan göçmenler, yerleşilen ülkedeki bankalardan almakta zorlandıkları kredileri genellikle faizsiz olarak yine tanıdıklarından sağlayabilmektedir. Son olarak işletmenin devamında aynı etnik gruptan veya aynı ülke arka planı olan kişilerle kurduğu ilişkiler sayesinde sadık bir müşteri kitlesi oluşabilmektedir.

Göçmenlerin kültürel sermayelerini yeni yerleştikleri ülkeye taşımaları da her durumda kolay olamamaktadır. Örneğin anavatandan alınan sertifika, diploma gibi belgelerin göç ile gelinen ülke hükümeti tarafından kabul görmeme ihtimali bulunmaktadır. Böyle durumlarda üniversite öğrenimi görmüş ve o ana kadar anavatanında yüksek nitelikli bir işte çalışan göçmenler mesleklerini yapamayacak duruma düşebilmektedir. Araştırma sonucunda Suriyeli göçmen girişimcilerin kültürel sermayelerini üç farklı yolla yeni yerleşilen ülkeye transfer ederek ekonomik bir değere dönüştürdükleri anlaşılmıştır. Bu yollardan ilki göçmenin Suriye’de elde ettiği diploma, sertifika gibi eğitim belgelerinin Türkiye'de de geçerliliğini sağlayabilmektir. Böylece daha önce Suriye'de yaptı̆̆ı mesleğe yönelik Türkiye'de işletme kurabilen girişimciler mevcuttur. Ancak çok kısıtlı sayıda göçmen bu yolla kültürel sermayesini Türkiye'ye taşıyabildiği tahmin edilmektedir. İkinci yol, etnik veya göç edilen ülke arka planına yaslanarak göçmen topluluğun ihtiyaç duyduğu ürün ve hizmetlere yönelik işletmeler açarak etnik kültürel sermayesini ekonomik değere dönüştürmektir. Saha araştırmasında görüşme yapılan katılımcıların büyük bölümü bu yolla girişimcilik faaliyetinde bulunmaktadır. Üçüncü ve son yol ise anayurtta kazanılmış özgün bilgi, beceri ve yeteneklerin yeni gelinen ülkeye transferi ve burada işletilmesidir. Yapılan saha araştırmasında görüşülen bazı katılımcılar bu yolla kültürel sermayesini Türkiye'de ekonomik değere tahvil edebilmektedir.

Göç Dergisi 
1970’li y1llarla birlikte göçmen girişimciliği faaliyetlerinin yoğunlaşması bu konu ile çeşitli çalışmanın yapılmasını ve yine bu konuyu açılamaya dönük yaklaşımların geliştirilmesini sağlamıştır. Göçmen girişimciliği genel olarak işletme, iktisat gibi alanların daha çok ilgilendiği bir konu olmakla birlikte son yıllarda sosyoloji alanında da konu ile ilgili çalışmaların yapıldığı görülmektedir. Göçmen girişimciliği ile ilgili yaklaşımlar son ylllarda konuyu tek yanlı ele aldıkları eleştirisine maruz kalmaktadır. Bu bağlamda Bourdieu'nun ilişkisel, bütünlüklü ve yapı-fail ikiliğini aşan bakışı göçmen girişimciliği çalışmalarında ilgi uyandırmaktadır. Bu çalışmanın Bourdieu'nun sermaye biçimleri kavramını Suriyeli göçmenlerin girişimcilik faaliyetleri bağlamında ele almasının konu ile ilgili literatür açısından katkı sunacağı düşünülmektedir. Daha çok çalışmada Bourdieu'nun ilişkisel sosyolojisinden faydalanılmasının göçmen girişimciliği alanına katkı sunacağı değerlendirilmektedir.

Göçmenlerin girişimcilik faaliyetlerine katılmalarının göç ile gelinen ülke ekonomisine önemli katkıları bulunmaktadır. Bu anlamda Türkiye'deki göçmenlerin girişimci olmalarını teşvik edici düzenlemeler ve politikalar geliştirilebilir. Göçmen girişimciler için eğitim/kurs, teşvikler, krediler ve yasal mevzuatta değişiklik gibi konularda adımlar atılması göçmen topluluğun ekonomik olarak güçlenmesini ve yeni pazarların ortaya çıkmasını sağlayabilir.

\section{EXTENDED ABSTRACT IN ENGLISH}

\section{The Role of Different Forms of Capital in Entrepreneurial Activities of Syrian Migrants in Turkey}

The protests and uprisings, which started in Tunisia in December 2010 and caused social and political transformations in many countries in North Africa and the Middle East, and which was called the "Arab Spring", turned into a civil war in Syria. Peaceful demonstrations in Syria were replaced by armed conflicts, and with the intensification of violence, Syrian citizens migrated to safer parts of the country and beyond Syria's border. The number of displaced people in Syria has exceeded 6 million, while the number of people living in Syria's neighboring countries has exceeded 5 and a half million. According to official records, Turkey had hosted nearly 4 million Syrian refugees by September 2021 (UNHCR, 2021). A small group $(1.5 \%)$ of Syrians in Turkey (GIGM, 2021) live in Temporary Accommodation Centers (GBM) established at the beginning of the Syrian migration, while the majority of them live in all cities of Turkey. In GBMs, the basic needs of Syrians are met, while those who live outside of these Centers survive with their expenses, with the help of various institutions. Syrians mostly face problems such as poor working conditions, low wages, and discrimination (TEPAV, 2021). In the early years of the Syrian migration, with the hope that the war would end soon, the Syrians who were living in the cities on the Syrian border of Turkey had started to migrate to the big cities of Turkey since their hopes of returning were exhausted.

Since 2011, thousands of companies have been established by Syrians in Turkey in various cities. In the report titled "Syrian Entrepreneurship and Refugee Start-ups in Turkey: Leveraging the Turkish Experience" published by TEPAV in 2019, it is stated that during eight years, Syrians in Turkey established more than 10,000 companies with an average of 7 employees (TEPAV, 2019). In Istanbul, 593 companies were founded in 2017, 976 in 2018, 563 in 2019, and 287 in 2020 (TOBB, 2021). According to the data of Istanbul Chamber of Commerce (İTO) and İstanbul Union of Tradesmen and Craftsmen (İSTESOB), the number of companies established by Syrians in Istanbul until August 2018 is 6086, while 5617 of which 
are registered with İTO and 469 with İSTESOB (İTO, 2018; İSTESOB, 2018). The existence of Syrian companies that continue their commercial activities without any registration to a vocational chamber or union indicates that the real number would be higher than this. Esenyurt stands out for being the second district in Istanbul where Syrians establish companies at most. Especially after 2015, a significant increase was observed in the number of Syrian companies in this district. The number of companies established by Syrian immigrants in Esenyurt is 760, of which 708 were registered with İTO and 52 with ISTESOB (İTO, 2018; İSTESOB, 2018).

The study aims to analyze in a Bourdieusian way how immigrant entrepreneurs utilize economic, cultural, and social capital in their entrepreneurial activities. This study is based on the in-depth interviews conducted among Syrian business owners in Esenyurt, İstanbul in 2018. The study aims to reach Syrian migrants who arrived in Turkey after the civil war in Syria that began in 2011 and who owned a business in the Esenyurt district. In this study, by using qualitative research methods and techniques, the experiences of Syrian migrant entrepreneurs are tried to be understood and interpreted.

The study consists of six sections. In the first section, the subject, aim, and methodology of the study are explained. In the second section, the definition and development of the concept of immigrant entrepreneurship are explained. In the third section, Bourdieu's concept of capital forms is emphasized. In the fourth section, the method of the research and the research process are explained. In the fifth section, the results of the research are presented. The role of various forms of capital in the activities of immigrant entrepreneurs and the transfer of different forms of capital are discussed in this section. In the sixth section, there are research results and suggestions.

\section{Kaynakça}

Akis-Kalaylıoğlu, Y. (2016). Transforming Constraints Into Strategies: The Role of Different Forms of Capital in The Status Passage of Documented Iranian Migrants in Ankara, Turkey. Yaymlanmamıs Doktora Tezi, Orta Doğu Teknik Üniversitesi. Ankara.

Arun, Ö. (2010). Türkiye'de Televizyon Alanının Sosyal Yapısı ve Televizyon Alanında Kültürel Tüketim Pratikleri. Yaynlanmamıs Doktora Tezi, Selçu Üniversitesi. Konya.

Atasü-Topcuoğlu, R. (2019). Syrian Refugee Entrepreneurship in Turkey: Integration and the Use of Immigrant Capital in the Informal Economy. Social Inclusion, 200-210.

Baycan-Levent, T., \& Kundak, S. (2006). İsviçre'nin Girişimci Türkleri. Uluslararası Girişimcilik Kongresi, Manas Üniversitesi Bildiri Kitabı, (s. 405-418). Bişkek.

Baycan-Levent, T., \& Nijkamp, P. (2009). Characteristics of migrant entrepreneurship in. Entrepreneurship and Regional Development, 375-397. doi:10.1080/08985620903020060

BMMYK. (2021, Eylül 4). Operational Portal Refugee Situation. United Nations High Commissioner for Refugees (UNHCR): https://data2.unhcr.org/en/situations/syria\#_ga=2.210286933.173777999 1.1518599064-1889419380.1491485864 adresinden alınd1

Bourdieu, P. (2010). Sermaye Biçimleri. M. M. Şahin, \& A. Z. Ünal içinde, Sosyal Sermaye: KuramUygulama-Eleștiri (M. M. Şahin, Çev., s. 49). İstanbul: Değişim Yayınları.

Bourdieu, P., \& Wacquant, L. (2003). Düşünümsel Bir Antropoloji İçin Cevaplar. İstanbul: İletişim Yayınları.

Butler, J., \& Greene, P. (1997). Ethnic Entrepreneurship: The Continuous Rebirth of American Enterprise. D. Sexton, \& R. Smilor. içinde, Entrepreneurship 2000 (s. 267-289). Chicago: Upstart Publishing Co. 
Chaganti, R., \& Greene, P. G. (2002). Who Are Ethnic Entrepreneurs? A Study of Entrepreneurs' Ethnic Involvement and Business Characteristics. Journal of Small Business Management, 20(2), 126143.

Chrysostome, E. (2010). The Success Factors of Necessity Immigrant Entrepreneurs: In Search of a Model. Thunderbird International Business Review, 137-152.

Çetin, İ. (2016). Türkiye'de Suriyeli Sığınmacıların Sosyal ve Kültürel Entegrasyonu. Sosyoloji Dergisi , 197-222.

David, A., Schäfer, S., \& Terstriep, J. (2021). Characteristics of migrant entrepreneurs: Asset in times of crisis? Gelsenkirchen: Forschung Aktuell.

Erbaş, H. (2019). Gidişlerden Kaçışlara Göç ve Göçmenler: Kuram, Yöntem ve Alan Yazıları. Ankara: Phoenix Yayınevi.

Faist, T. (2003). Uluslararası Göç ve Ulusaşırı Toplumsal Alanlar. İstanbul: Bağlam Yayınları.

Fregetto, E. (2004). Immigrant and Ethnic Entrepreneurship: A U.S. Perspective. H. (. Welsch içinde, Entrepreneurship the way ahead (s. 253-268). New York: Routledge.

Akis-Kalaylıoğlu, Y. (2016). Transforming Constraints Into Strategies: The Role of Different Forms of Capital in The Status Passage of Documented Iranian Migrants in Ankara, Turkey. Yaymlanmamıs Doktora Tezi, Orta Doğu Teknik Üniversitesi. Ankara.

Arun, Ö. (2010). Türkiye'de Televizyon Alanının Sosyal Yapısı ve Televizyon Alanında Kültürel Tüketim Pratikleri. Yayılanmamıs Doktora Tezi, Selçuk Üniversitesi. Konya.

Atasü-Topcuoğlu, R. (2019). Syrian Refugee Entrepreneurship in Turkey: Integration and the Use of Immigrant Capital in the Informal Economy. Social Inclusion, 200-210.

Baycan-Levent, T., \& Kundak, S. (2006). İsviçre'nin Girişimci Türkleri. Uluslararası Girişimcilik Kongresi, Manas Üniversitesi Bildiri Kitabı, (s. 405-418). Bişkek.

Baycan-Levent, T., \& Nijkamp, P. (2009). Characteristics of migrant entrepreneurship in. Entrepreneurship and Regional Development, 375-397. doi:10.1080/08985620903020060

BMMYK. (2021, Eylül 4). Operational Portal Refugee Situation. United Nations High Commissioner for Refugees (UNHCR): https://data2.unhcr.org/en/situations/syria\#_ga=2.210286933.173777999 1.1518599064-1889419380.1491485864 adresinden alınd1

Bourdieu, P. (2010). Sermaye Biçimleri. M. M. Şahin, \& A. Z. Ünal içinde, Sosyal Sermaye: KuramUygulama-Eleştiri (M. M. Şahin, Çev., s. 49). İstanbul: Değişim Yayınları.

Bourdieu, P., \& Wacquant, L. (2003). Düşünümsel Bir Antropoloji İçin Cevaplar. İstanbul: İletişim Yayınları.

Butler, J., \& Greene, P. (1997). Ethnic Entrepreneurship: The Continuous Rebirth of American Enterprise. D. Sexton, \& R. Smilor. içinde, Entrepreneurship 2000 (s. 267-289). Chicago: Upstart Publishing Co.

Chaganti, R., \& Greene, P. G. (2002). Who Are Ethnic Entrepreneurs? A Study of Entrepreneurs' Ethnic Involvement and Business Characteristics. Journal of Small Business Management, 20(2), 126143.

Chrysostome, E. (2010). The Success Factors of Necessity Immigrant Entrepreneurs: In Search of a Model. Thunderbird International Business Review, 137-152.

Çetin, İ. (2016). Türkiye'de Suriyeli Sığınmacıların Sosyal ve Kültürel Entegrasyonu. Sosyoloji Dergisi, 197-222.

David, A., Schäfer, S., \& Terstriep, J. (2021). Characteristics of migrant entrepreneurs: Asset in times of crisis? Gelsenkirchen: Forschung Aktuell.

Erbaş, H. (2019). Gidişlerden Kaçı̧lara Göç ve Göçmenler: Kuram, Yöntem ve Alan Yazıları. Ankara: Phoenix Yayınevi.

Faist, T. (2003). Uluslararası Göç ve Ulusaşırı Toplumsal Alanlar. İstanbul: Bağlam Yayınları.

Fregetto, E. (2004). Immigrant and Ethnic Entrepreneurship: A U.S. Perspective. H. (. Welsch içinde, Entrepreneurship the way ahead (s. 253-268). New York: Routledge.

Göç İdaresi Genel Müdürlüğü (GİGM). (2021, Eylül 9). Geçici Koruma. T.C. Göç İdaresi Genel Müdürlüğü: https://www.goc.gov.tr/gecici-koruma5638 adresinden alındı 
Gültekin, M. N., Giritlioğlu, İ., Karadaş, Y., Soyudoğan, M., Leyla-Kuzu, Ş., Gülhan, S. T., . . . Incetahtac1, N. (2018). Gaziantep'teki Suriyeliler: Uyum, Beklentiler ve Zorluklar. Gaziantep: Gaziantep Üniversitesi Yayınları.

Güngördü, S. (2018). Göçmen Girişimcilerin Kişilik Özellikleri ve Göçmen Girişimcilik Üzerine Alg1ları. Yayınlanmamıs Yüksek Lisans Tezi, İzmir Kâtip Celebi Üniversitesi. İzmir.

İSTESOB. (2018, 7 25). İstanbul'da kurulan İSTESOB'a kayıtlı Suriyeli İşletmeler. İstanbul.

İTO. (2018, 07 27). İstanbul'da kurulan Suriyeli işletmeler. İstanbul.

İTO. (2021, 9 10). İstanbul'da Kurulan Suriyeli İşletmeler. İstanbul.

Karan, O. (2019). Suriyeli Mültecilerin Esnaflaşmasını Anlamada Bourdieucu Yaklaşımın Olanakları. İstanbul Üniversitesi Sosyoloji Dergisi, 249-276.

Kaya, A. (2017). Suriyeli Mültecilerin Kentsel Alandaki Halleri. Toplum ve Bilim, 42-68.

Kohlmeier, M., \& Schimany, P. (2005). The Impact of Immigration on Germany's Society. Nürnberg: Federal Office for Migration and Refugees Migration and Integration Research Department.

Light, I. (1972). Ethnic Enterprise in America: Business and Welfare Among Chinese, Japanese, and Blacks. Berkeley: University of California Press.

Neuman, W. L. (2017). Toplumsal Arastırma Yöntemleri: Nitel ve Nicel Yaklaşımlar. Ankara: Yayınodası Yayıncilik.

Neumann, S. (2011). Farklılığın Olumsuz Algılanması ve Sınıflandırılması: Kanada ve Almanya'da, Ülke İçinde Eğitim Görmüş Yüksek Vasıflı Göçmenlerin Tanınmama, Aşağı Görülme ve Ayrımcılık Tecrübeleri. A.-M. Nohl, K. Schıttenhelm, O. Schmidtke, \& A. Weib içinde, Göç ve Kültürel Sermaye (s. 300-318). İstanbul: Kitap Yayınevi.

Nohl, A.-M. (2008). Kültürel Sermayenin Göçü: Ülkesinde Yüksek Öğrenim Görmüş Göçmenlerin Almanya İş Piyasasındaki Olanak Ve Sınırlılıkları. Eğitim Bilim Toplum, 38-49.

OECD. (2010a). Open for Business: Migrant Entrepreneurship in OECD Countries. OECD Publishing.

Roberts, G. J. (2009). Entrepreneurship: An African Caribbean Perspective. A thesis submitted for the degree of Doctor of Philosophy. The University of Birmingham. England.

Sahin, M., Nijkamp, P., \& Rietdijk, M. (2009). Cultural diversity and urban innovativeness: personal and business characteristics of urban migrant entrepreneurs. Innovation - The European Journal of Social Science Research, 251-281. doi:10.1080/13511610903354364

Strüder, I. R. (2003). Do concepts of ethnic economies explain existing minority enterprises? The Turkish speaking economies in London. Research papers in Environmental and Spatial Analysis Series 88. London. http:// citeseerx.ist.psu.edu/viewdoc/download?doi=10.1.1.734.3448\&rep=rep1\&type=pdf adresinden alınd1

Sunata, U. (2018). Suriyeli Sığınmacıların Emek Piyasasına Katılımları. B. Kartal, \& U. Manço içinde, Beklenmeyen Misafirler: Suriyeli Siğınmacilar Penceresinden Türkiye Toplumunun Geleceği (s. 169-195). Londra: Transnational Press London.

TEPAV. (2019). Syrian Entrepreneurship and Refugee Start-ups in Turkey: Leveraging the Turkish Experience. Ankara: TEPAV.

TEPAV. (2021). İsgücü Piyasasinda Suriyeliler. Ankara: TEPAV.

TOBB. (2021, 09 21). Kurulan/Kapanan Şirket Istatistikleri. Türkiye Odalar ve Borsalar Birliği: https://www.tobb.org.tr/BilgiErisimMudurlugu/Sayfalar/KurulanKapananSirketistatistikleri.php adresinden alınd 1

U.S. Department of Commerce. (1997). The State of Small Business: A Report of the President. Washington, DC: U.S. Government Printing Office.

Wacquant, L. (2016). Pierre Bourdieu: Hayatı, Eserleri ve Entelektüel Gelişimi. G. Çeğin, E. Göker, A. Arlı, \& Ü. Tatlican içinde, Ocak ve Zanaat (s. 62). İstanbul: İletişim Yayıncılık.

Waldinger, R., Aldrich, H., \& Ward, R. (1990). Opportunities, Group Characteristics, and Strategies. R. Waldinger, H. Aldrich, \& R. W. Associates içinde, Ethnic Entrepreneurs: Immigrant Business in Industrial Societies (s. 13-48). California: Sage Publication.

Yarc1, S. (2011). Pierre Bourdieu'da Sosyal Sermaye. Akademik Incelemeler Dergisi, 125-135.

Yıldırım, A., \& Şimşek, H. (2018). Sosyal Bilimlerde Nitel Araştırma Yöntemleri. Seçkin Yayıncılık: Ankara. 